\title{
Incremental Cost Analysis of Advanced Concept CAES Systems
}

Corey A. Knutsen

Knutsen Research Services

September 1979

Prepared for

Pacific Northwest Laboratory

Under Agreement B-56754-A-L

Pacific Northwest Laboratory

Operated for the U.S. Department of Energy

by Battelle Memorial Institute 


\title{
NOTICE
}

This report was prepared as an account of work sponsored by the United States Covernment. Neither the United States nor the Department of Energy, nor any of their employees, nor any of their contractors, subcontractors, or their employees, makes any warranty, express or implied, or assumes any legal liability or responsibility for the accuracy, completeness or usefulness of any information, apparatus, product or process disclosed, or represents that its use would not infringe privately owned rights.

The views, opinions and conclusions contained in this report are those of the contractor and do not necessarily represent those of the United States Government or the United States Department of Energy.

\author{
PACIFIC NORTHWEST LABORATORY \\ operated by \\ BATTELLE \\ for the \\ UNITED STATES DEPARTMENT OF ENERGY \\ Under Contract EY-76-C-06-1830
}
Primed in the United States of America Available from
National Technical Information Service United States Department of Commerce 5285 Port Royal Road
Springfield, Virginia 22151

Price: Printed Copy $\mathbf{S}$ $\because$ Microfiche $\$ 3.00$

- Pages

NTIS

Selling Price

$001-025$

$026-050$

$051-1775$

076-100

$101-125$

$126-150$

$151-175$

$176-200$

$201-225$

226.250

$\$ 4.00$
$\$ 4.50$
$\$ 5.25$
$\$ 6.00$
$\$ 5.50$
$\$ 7.25$
$\$ 8.00$
$\$ 9.00$
59.25
59.50
510.75
$\$ 11.00$


PNL-3118

INCREMENTAL COST ANALYSIS OF ADVANCED CONCEPT CAES SYSTEMS

by

Corey A. Knutsen

Knutsen Research Services

September 1979

Prepared for Pacific Northwest Laboratory Under Agreement B-56754-A-L

Pacific Northwest Laboratory

Richland, Washington 99352 

SUMMARY

The costs of compressed air energy storage (CAES) systems using thermal energy storage (TES) are compared to the costs of CAES systems without TES and simple cycle gas turbine systems. Comparisons are made in terms of the system energy costs levelized over the operating life of the systems. These are in 1985 price levels which is the assumed first year of operation for the systems in this study.

The two systems with one stage of TES, the hybrid systems, gain moderate fuel savings at the expense of a slightly higher levelized cost of electricity. If the TES is placed at an intermediate pressure stage instead of a high pressure stage, as it is in one of these systems, the fuel savings are somewhat larger. The levelized cost is also somewhat larger except when 1985 fuel cost is near the high end of the range studied.

The systems using two stages of TES, the adiabatic systems, were designed to operate without the use of turbine fuel. This results in a levelized cost that is much larger than the other CAES systems under base case conditions. However, the levelized costs for these systems also exhibit a substantial sensitivity to both compression energy and turbine fuel costs. If a moderately low 1985 compression energy cost of 20 $\mathrm{mils} / \mathrm{kWh}$ is assumed, these systems cost less to operate than the reference system above fuel costs of about $\$ 6.00 / \mathrm{GJ}\left(\$ 6.33 / 10^{6} \mathrm{Btu}\right)$ in 1985 dollars.

The cost advantage of allowing the compressor temperatures in one of the adiabatic systems to rise above the limits of currently available equipment is about $7 \mathrm{mills} / \mathrm{kWh}$ under base case conditions. If the cost of the higher temperature compressors is more tnan about $75 \%$ above the cost of conventional equipment, this advantage disappears.

Because of its heavy dependence on turbine fuel, the simple cycle gas turbine system levelized cost is greater than the reference CAES system levelized cost for most conditions studied. Only when moderate to low fuel costs are assumed and when compression energy cost is at the high end of the range studied, does the simple cycle turbine cost less. 

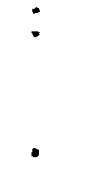


\section{ACKNOWLEDGMENTS}

The author wishes to thank the members of the Pacific Northwest Laboratory staff who supported the work in this paper. The program and technical direction obtained from Walt Loscutoff, Rudy Allemann, Mike McKinnon and Steve Schulte were critical to the design and implementation of the project. In addition, the work of Gary DeHaan on the CAES thermodynamic cycle analyses and of Kevin Drost on the TES cost estimates, contained in Appendixes $A$ and $B$ respectively, provided essential material in those two important areas. Of course, the responsibility for any errors or lack of clarity remain with the author. 


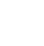


TABLE OF CONTENTS

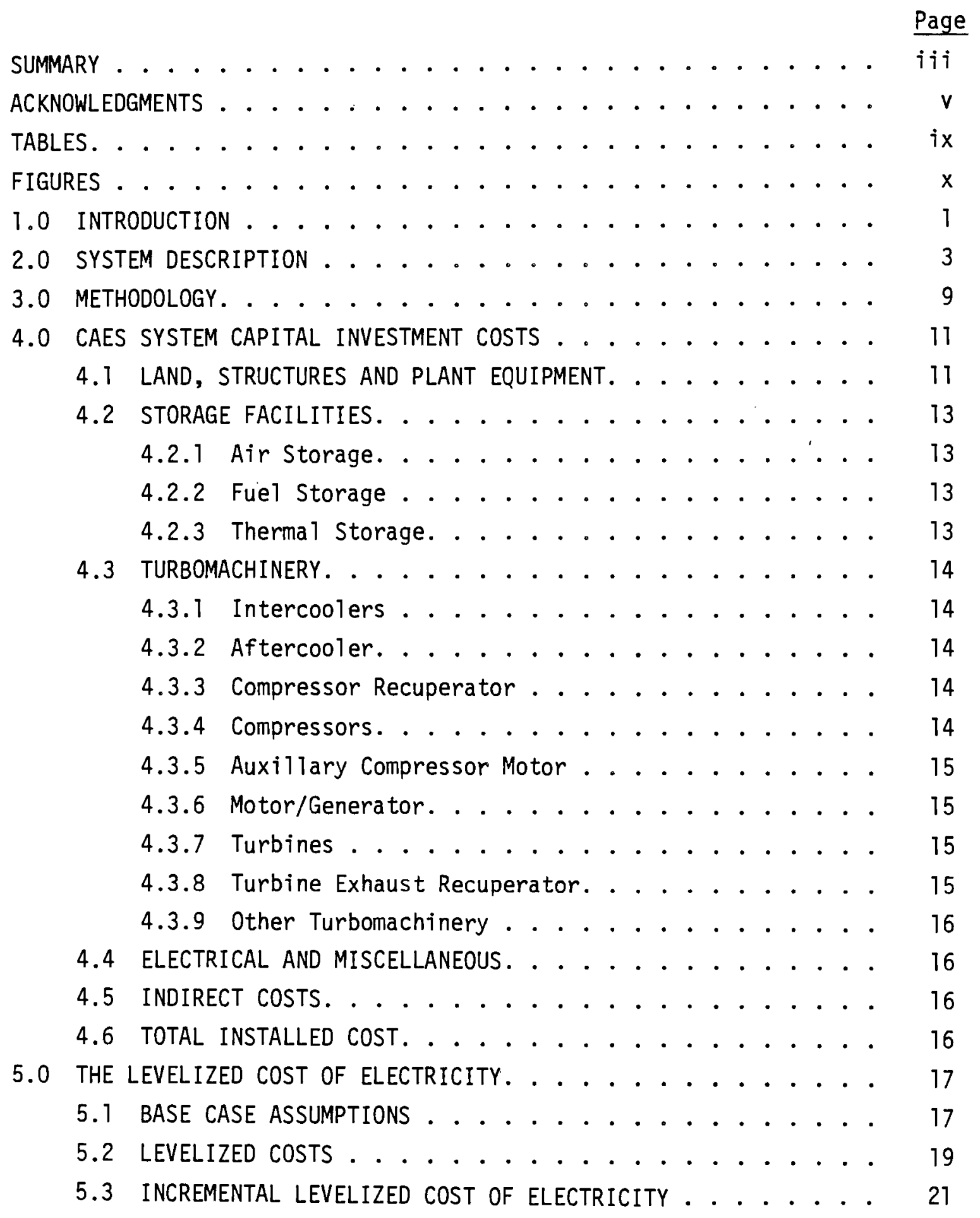


6.0 SENSITIVITY ANALYSIS

6.7 CAPACITY FACTOR . . . . . . . . . . . . . . 23

6.2 TURBINE FUEL COST . . . . . . . . . . . . . . . 27

6.3 COMPRESSION ENERGY. . . . . . . . . . . . . . 30

REFERENCES. . . . . . . . . . . . . . . . . . . . 32

APPENDIX A. . . . . . . . . . . . . . . . . . . . 33

APPENDIX B. . . . . . . . . . . . . . . . . . . . . . 43

APPENDIX C. . . . . . . . . . . . . . . . . . . . . 49 
$\underline{\text { TABLES }}$

Page

1 Comparison Systems. . . . . . . . . . . . . . . . 3

2 CAES/TES Capital Cost Estimates . . . . . . . . . . . 12

3 Performance Variables . . . . . . . . . . . . . . 13

4 Base Case Economic Assumptions. . . . . . . . . . . . . 18

5 The Levelized Cost of Electricity (mills/kWh in 1985) . . . . . 20

6 Incremental Levelized Costs of Electricity for the Base Case (mills/kWh in 1985) . . . . . . . . . . . . 21

$7 A$ The Results of the Sensitivity Analysis Using $30 \mathrm{mills} / \mathrm{kWh}$ Compression Energy Cost (mills/kWh in 1985) . . . . . . . . . . 24

7B The Results of the Sensitivity Analysis Using $20 \mathrm{mills} / \mathrm{kWh}$ Compression Energy Cost (mil1s/kWh in 1985) ........ . 25

A-1 Reference CAES System Thermodynamic Cycle Data. . . . . . . 36

A-2 TES-1 System Thermodynamic Cycle Data . . . . . . . . . . 37

A-3 TES-2 System Thermodynamic Cycle Data . . . . . . . . . . 38

A-4 TES-3 System Thermodynamic Cycle Data . . . . . . . . . . 39

A-5 TES-4 System Thermodynamic Cycle Data . . . . . . . . . . . 40

B-1 TES Cost Parameters ............... . . 46 


\section{FIGURES}

Page

1 Reference CAES System . . . . . . . . . . . . . . 4

2 TES-1 System. . . . . . . . . . . . . . . . . 4

3 TES-2 System. . . . . . . . . . . . . . . . . 5

4 TES-3 System. . . . . . . . . . . . . . . . . 5

5 TES-4 System. . . . . . . . . . . . . . . . . . 6

6 A Sensitivity to Changes in Capacity Factor Using $30 \mathrm{mill} / \mathrm{s} / \mathrm{kWh}$ Compression Energy Cost. . . . . . . . . . . 26

6B Sensitivity to Changes in Capacity Factor Using $20 \mathrm{mi}\rceil \mathrm{l}$ /kWh Compression Energy Cost. . . . . . . . . . 28

$7 A$ Sensitivity to Changes in Turbine Fuel Cost and Fuel Cost Escalation Using $30 \mathrm{mills} / \mathrm{kWh}$ Compression Energy Cost . . . . . . . . . . . . . . . . . . 29

$7 \mathrm{~B}$ Sensitivity to Changes in Turbine Fuel Cost and Fuel Cost Escalation Using $20 \mathrm{mills} / \mathrm{kWh}$ Compression Energy Cost . . . . . . . . . . . . . . . . . 30

8 Sensitivity to Changes in Compression Energy Cost . . . . . . 31 
INCREMENTAL COST ANALYSIS OF ADVANCED CONCEPT CAES SYSTEMS

\subsection{INTRODUCTION}

A Compressed Air Energy Storage (CAES) system provides an electric utility with both storage and peaking capacity. It stores the energy from excess base load electricity in the form of compressed air in below ground caverns. When peaking capacity is needed, the compressed air is supplied to peaking turbines to complete the gas turbine cycle.

The compressors in a CAES system develop heat that must be removed from the air before it is stored. This heat can either be rejected to the atmosphere or stored in Thermal Energy Storage (TES) units. If stored, the energy can be used to heat the compressed air as it is being sent to the gas turbine. In this way, TES can reduce or eliminate the need for turbine fuel. However, the use of TES increases the system capital cost.

It is the objective of this report to compare the costs of a reference CAES system to those for advanced concept CAES systems that employ TES. The costs of a simple cycle gas turbine are included in the analys is so that the costs of all the CAES systems can be compared to the cost of a conventional peaking system.

The measure of comparison is the levelized cost of electricity (mills/kWh) in 1985 price levels, the assumed first year of CAES operation. The reference system cost is compared to the cost of the other systems and the difference in the incremental levelized cost is calculated for a set of base case assumptions. The sensitivity of the incremental costs to the assumed value for three critical parameters -- capacity factor, turbine fuel cost and compression energy cost (charging cost) -.- is tested over a range of values for these parameters. 


\subsection{SYSTEM DESCRIPTION}

Six peaking/storage systems, listed in Table 1, are compared in this paper. The reference CAES system is compared to four advanced concept CAES systems that employ TES. The four TES systems were chosen as a representative sample of the commonly proposed advanced CAES systems. Thermodynamic cycle data (Appendix A), performance variables (Table 3), and schematic diagrams (Figures 1 through 5 ) are provided for the CAES systems to aid in their comparison. The sixth system is a simple cycle gas turbine. It is included so that the CAES systems can be compared to the cost of a conventional peaking technology. The abbreviated names provided in the table are used throughout the remainder of the paper.

A CAES system provides both storage and peaking capacity by separating the compression and expansion parts of a conventional gas turbine cycle. At times when a utility has excess base load electricity, that energy is used to compress air, which is stored in below-ground caverns. When peaking capacity is required, the compressed air is supplied to an aboveground peaking turbine.

TABLE 1. Comparison Systems

\begin{tabular}{ll}
$\qquad \begin{array}{c}\text { System } \\
\text { Reference CAES }\end{array}$ & Abbreviated Name \\
\cline { 2 - 2 } Hybrid & Reference \\
Double-Stage/Adiabatic (Advanced) & TES- 1 \\
Double-Stage/Adiabatic (Near-Term) & TES-2 \\
Glendenning A-5 Hybrid & TES-3 \\
Simple Cycle Gas Turbine & TES-4
\end{tabular}




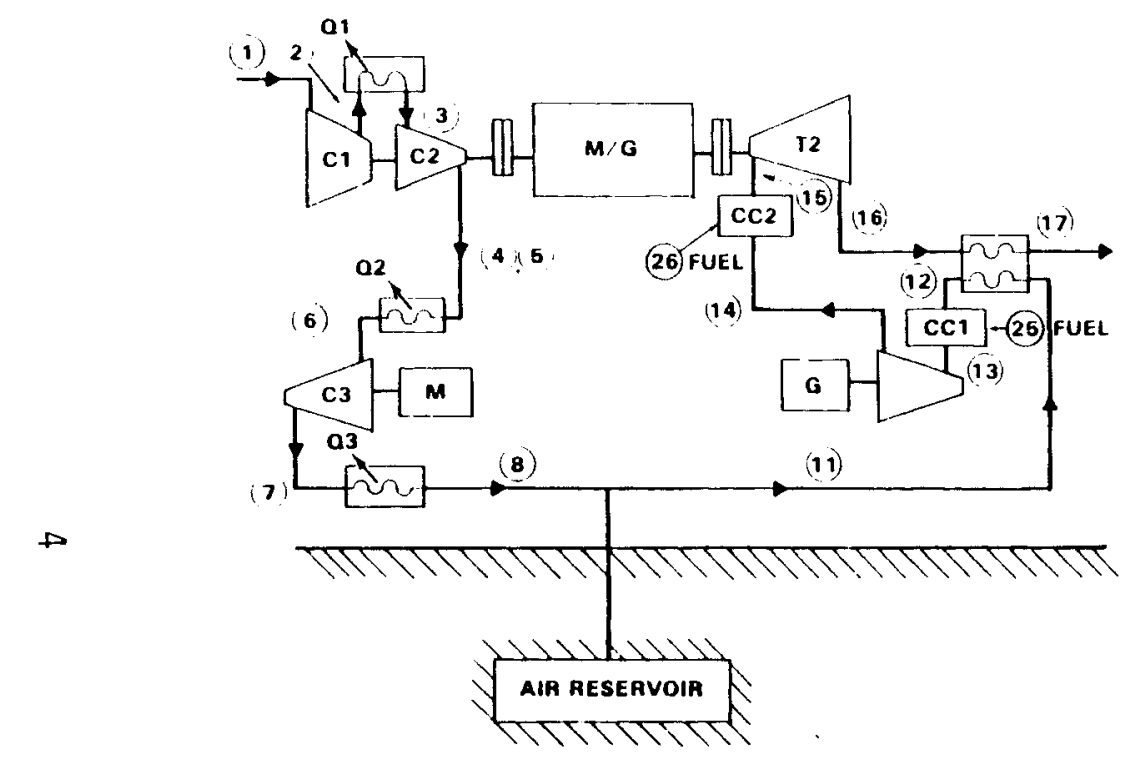

FIGURE 1. Reference CAES System

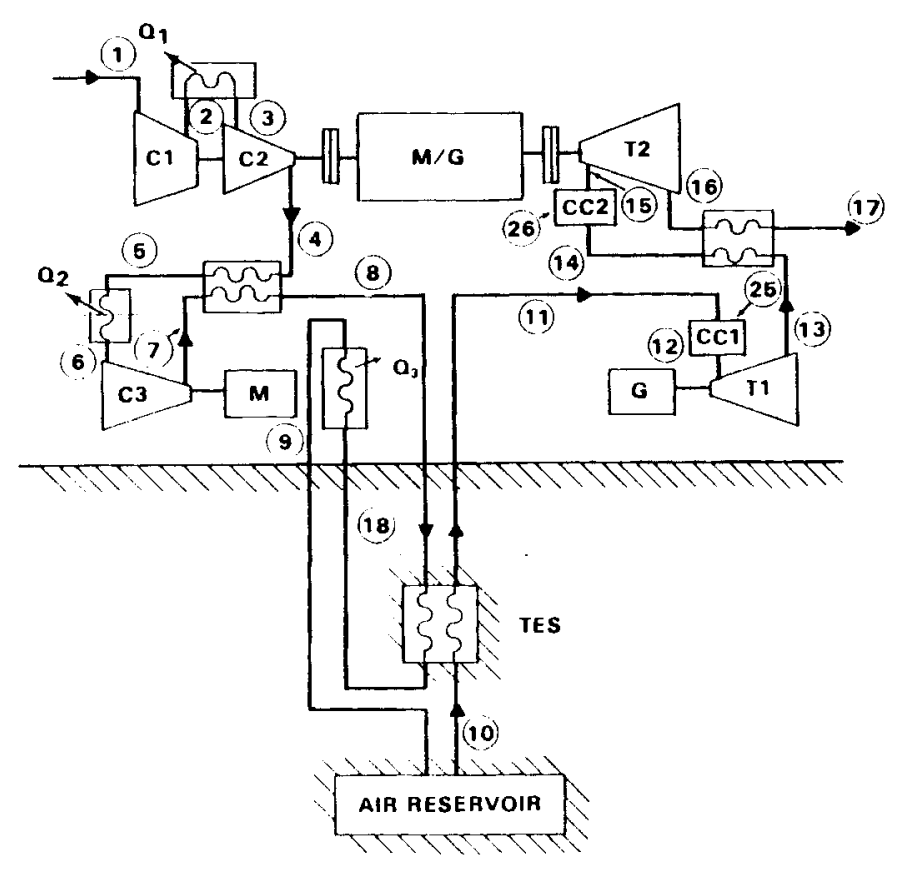

FIGURE 2. TES-1 System 


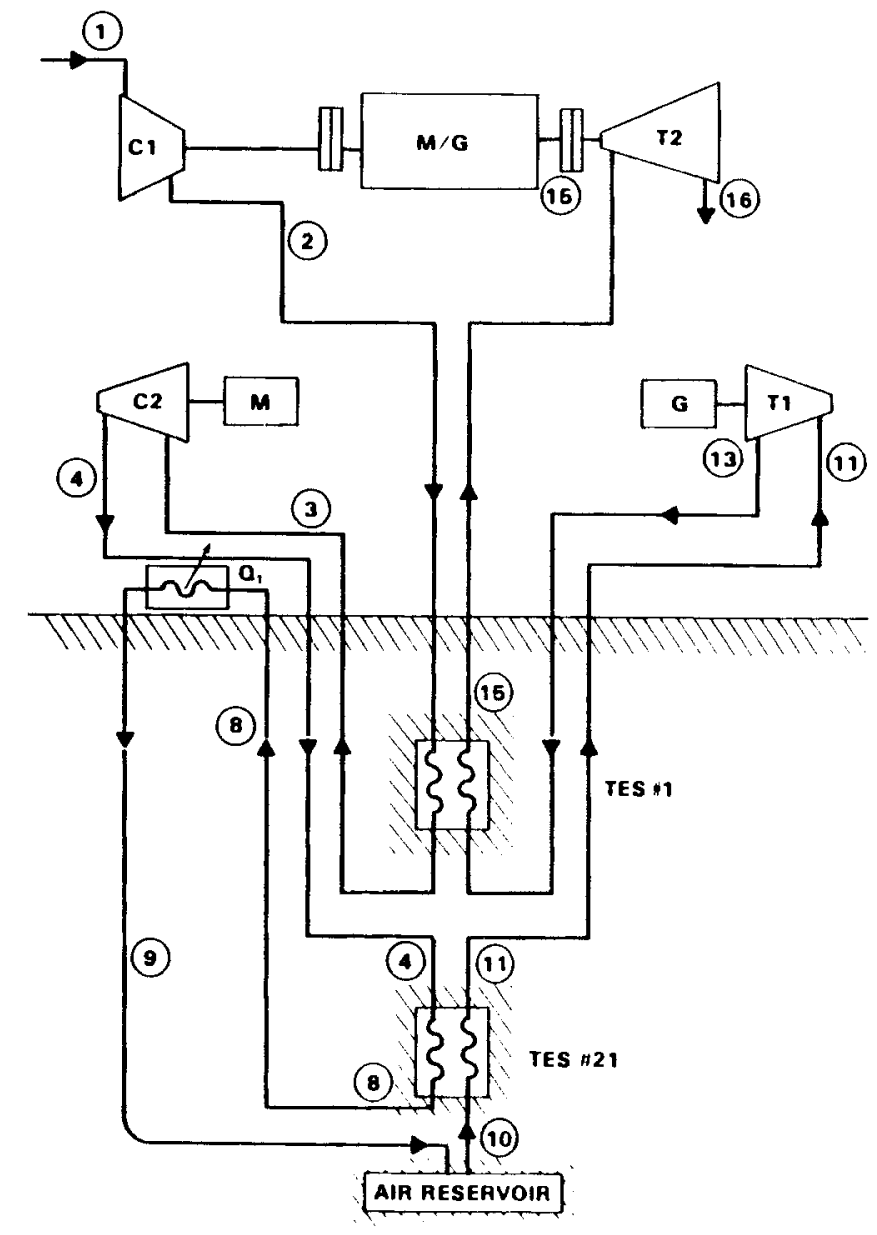

FIGURE 3. TES-2 System

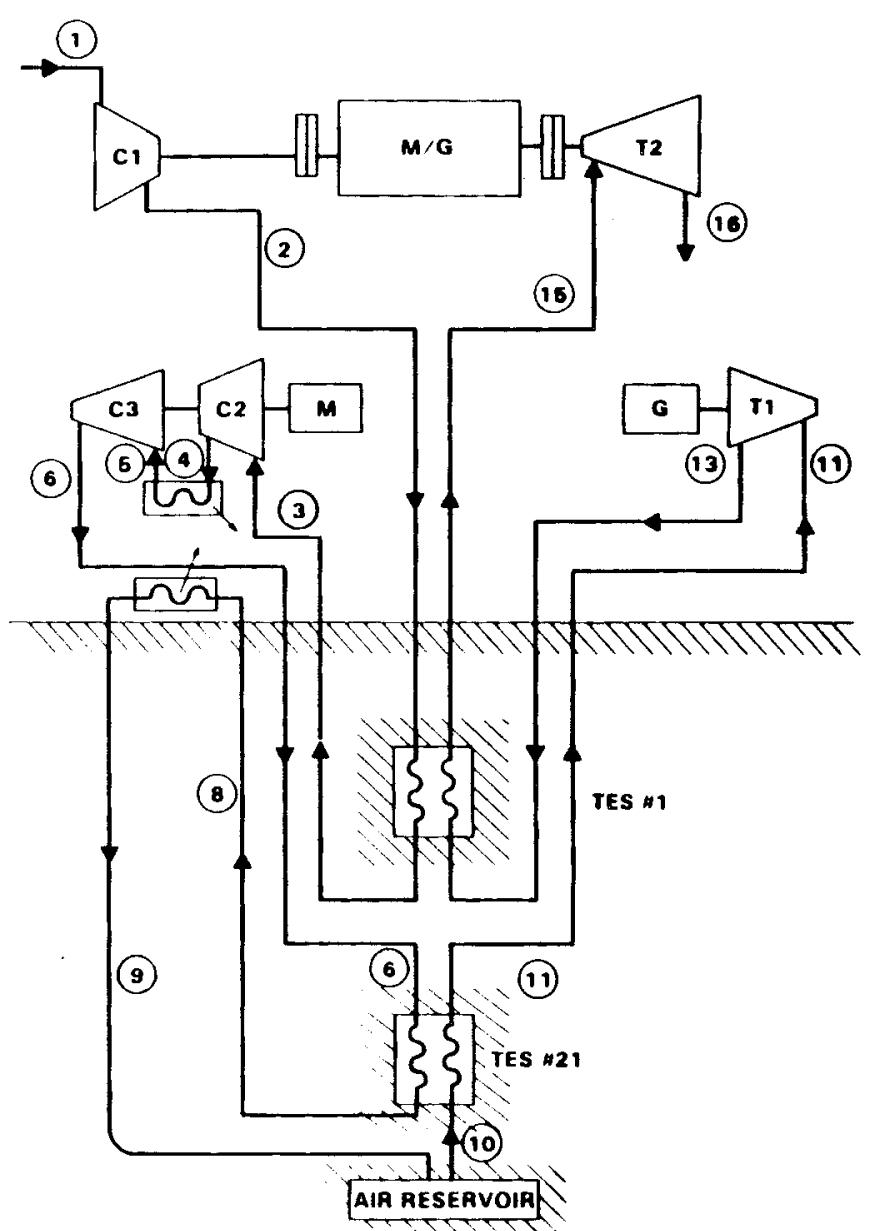

FIGURE 4. TES-3 System 


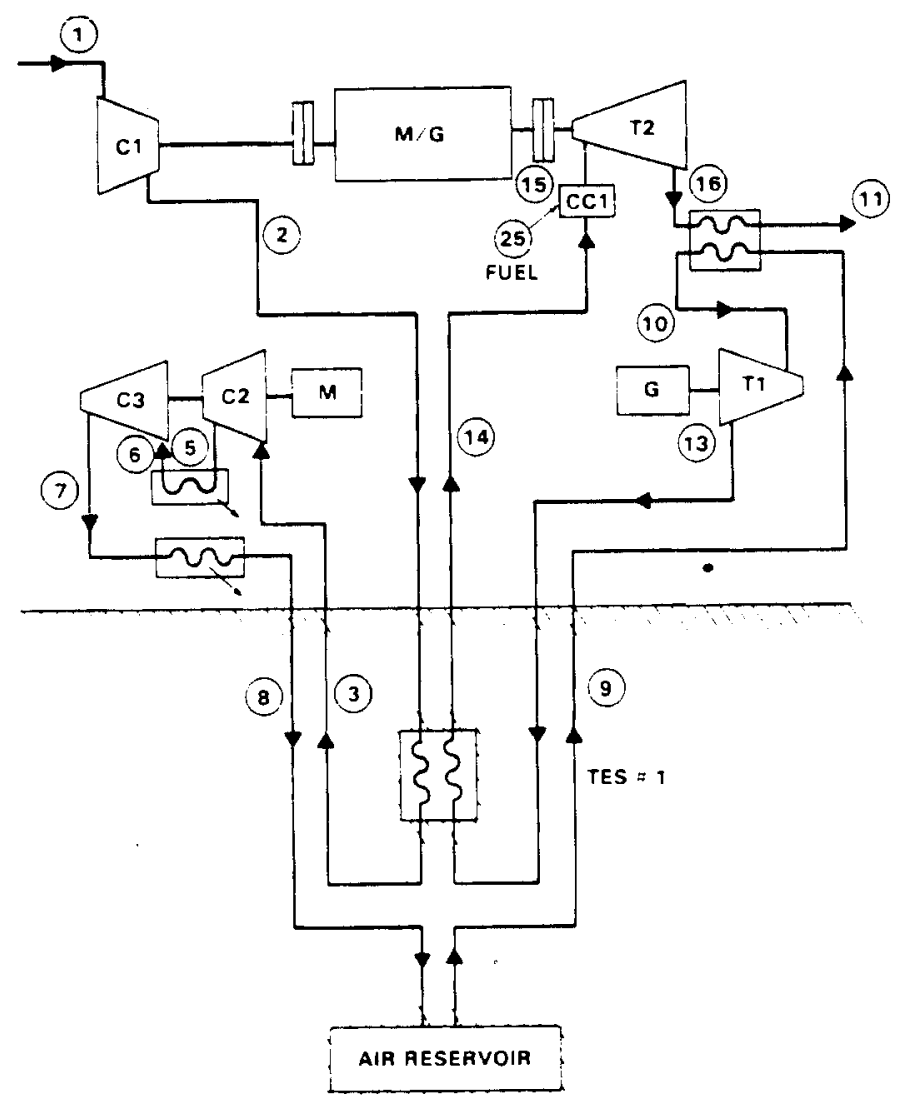

\section{FIGURE 5. TES-4 System}

The reference CAES system uses mined hard rock air storage caverns which are hydro-compensated. The caverns are sized for 20 hours of storage (as are the TES chambers in the advanced concept systems). It is assumed that the reference system generates electricity 8 hours, five days a week. The 20 hour storage capacity is provided so that the caverns can be charged when base load electricity is available, both at night during the week and on weekends. The air flow rate during charging is assumed to be the same as during generation. These operating assumptions are the same for aij CAES systems in this anaiysis.

In the TES-1 system, illustrated in Figure 2, the base CAES design is augmented with one stage of TES. This feature reduces turbine fuel consumption by first storing some of the heat of compression in the TES 
chamber and then using that energy to heat the air on its way to the turbine. Also, the TES-1 system uses a recuperator to transfer some of the heat of the first stages of compression to the air flowing to the TES chamber. In the reference system, the excess heat is rejected through the intercooler at this point in the system.

The TES- 2 and TES- 3 systems, illustrated in Figures 3 and 4 , are designed with two TES stages to eliminate the use of turbine fuel altogether. These two systems differ from each other primarily in the level of compressor outlet temperature allowed. The state-of-the-art upper limits for these temperatures are assumed to be roughiy $505^{\circ} \mathrm{K}\left(450^{\circ} \mathrm{F}\right)$ for the high pressure stages and $616^{\circ} \mathrm{K}\left(650^{\circ} \mathrm{F}\right)$ for the low pressure stages. The TES-2 system is an advanced system in that compressor outlet temperatures are allowed to rise above these upper limits. The TES-3 system is designed to stay within these constraints and thus uses near-term technology.

The TES-4 system differs from the TES-1 system in the placement of the TES chamber; this can be seen by comparing Figure 5 to Figure 2. As identified in Table 1, placing the TES chamber in an intermediate pressure stage in the TES-4 system results in a configuration similar to the Glendenning A-5 hybrid configuration.

The GT system is a simple cycle gas turbine system. No specific detailed design was used. The GT system is described entirely, for the purposes of this paper, by the estimates for capital cost and heat rate used later. 


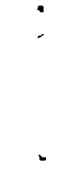

.

. 


\subsection{METHODOLOGY}

A levelized revenue requirements approach is used to calculate the levelized cost of electricity in this paper. This method follows the recommendation of the EPRI Technical Assessment Guide (TAG) (1978, p. $V-1)$. In most instances, the values used for the parameters required to make the calculations are those suggested in the TAG. This includes, for example, the use of the first year of operation of the CAES systems, here assumed to be 1985, as the base year for all cost levels and present value calculations (EPRI 1978, p. V-14). It is hoped that, by using the TAG approach the results reported here for CAES systems may be easily compared to the results of other studies involving similar or alternate technologies.

The calculation of the levelized costs of electricity is preceded by the development of capital cost estimates for the systems. The capital cost estimates for the reference system are taken from a previous study (Hobson, et a1. 1978). The costs for the TES systems are derived by making changes in the reference system costs where performance or system configuration differences warrant. The capital cost estimate for the GT system is taken from the TAG. Differences in compression energy use and turbine fuel consumption are derived from calculated differences in performance for the CAES systems. The turbine heat rate for the GT system is taken from the TAG.

The levelized cost of electricity for the reference system is calculated in terms of four categories: capital, operation and maintenance $(0 \& M)$, turbine fuel and compression energy. The calculations proceed by accumulating the present value of the costs for each category over the assumed 35-year operating life. The cumulative present value is converted to level annual costs and is divided by the annual production of kilowatt hours to obtain the unit cost $(\$ / \mathrm{kWh})$. The calculations of the levelized costs for the TES systems and the GT system follow the same pattern. The incremental cost of electricity is then calculated for the TES and GT systems to highlight the difference between their levelized costs and that for the reference system. 
The incremental levelized costs are tested for sensitivity to changes in the values of capacity factor, turbine fuel cost, and compression energy cost. Al1 but one of the parameters are held at their nominal value. This one is varied over a range of likely values and the change in incremental levelized cost is recorded for each of the systems. The process is repeated for several important parameters. 


\subsection{CAES SYSTEM CAPITAL INVESTMENT COSTS}

Capital cost estimates for the reference CAES system were obtained from a study conducted by Acres America Inc. (a) The construction scenario used in that study, and adopted here, calls for the construction of a 750 MW CAES system over a 6.5 year period with all three 250 MW units cormencing operation by January 1985. All costs are price level adjusted to that date, as shown in Table 2.

The reference CAES system cost estimates are used as a basis for equipment costs in the TES systems. They are scaled up or down on the bas is of calculated performance and operational differences as compared to the reference CAES system (see Appendix A and Table 3). The scaling factor in all cases is 1.0. For example, if the air flow required for a TES system were twice that of the reference system, the cost for air storage in that TES system would be estimated as twice the reference system cost. This simplified scaling assumption does not take into account the full effect of economics of scale. However, it was thought to be adequate for this preliminary comparative analysis.

The derivation of the cost differences is described below in order of the major categories listed in Table 2. The categories, in general, match those in the Acres America study. There has been some grouping of categories where there were no significant cost differences to describe. The cost estimate for the GT system is discussed in a later section.

\subsection{LAND, STRUCTURES AND PLANT EQUIPMENT}

This category includes costs for land and land rights, all the buildings and site improvements, waste disposal and some fuel handling facilities. The cost in this category is lower for the TES-2 and TES-3 systems by an amount equal to the cost of the fuel handling facilities. Since these TES systems do not use turbine fuel, they do not require these facilities.

(a) Hobson et al. 1978, pp. 12-24 to 12-28, Figure 12-2, Table 12-2 


\section{TABLE 2. CAES/TES Capita1 Cost Estimates}

\section{Category}

1.0, 1.1 Land, Structures and

1.2 Plant Equipment

1.3 Storage Facilities

Air Storage

Fuel Storage

Thermal Storage

1.4 Turbomachinery

Intercoolers

Aftercooler

Compressor Recuderator

Compressors

Auxiliary Combressor

Mtr.

Motor/Generator

Turbines

Turbine Exhaust

Recuperator

Other Turbomachinery

$1.5,1.6$ Electrical and Misc.

TOTAL DIRECT COSTS (\$1978)

Engineering and Misc.

Contingency

Escalation

Interest during

Construction

TOTAL INSTALLED COST (\$1985)

Plant Capacity (MW)

Cost/kw (\$1985)
Reference

CAES

TES-

$\underline{T E S-2}$

TES-3 IES-4

$\$ 5,538 \quad \& \quad 5,538 \quad \$ \quad 5,288 \quad \$ \quad 5,288 \quad \$ \quad 5,538$

34,509

428

35,475

428

66,188

72,400

42,998

$--$

14,813

$59,414 \quad 63,940$

428

19,864

1,664

780

$-$

24,972

1,47

8,140

27,644

$-$

22,983

18,354

--

22,983

18,831

$92 \quad 881$

881

54,039

--

55,713

556

8,501

22,056

9.519

22.056

7,824

22,983

8,298

22,983

38,444

35,189

38,4

10,625

10,625

20,520

$--$

20,520

32,039

$\$ 150,410$

$\$ 177,523$

10,625

10,625

.

22,983

22,823

22,562

25,946

26,628

30,623

$\$ 282,16$

$\$ 299,0.92$

$\$ 183,372$

68,893

81,312

42,324

44,864

51,593

136,995

27,506

48,673

129,240

36,995

31,632

83,991

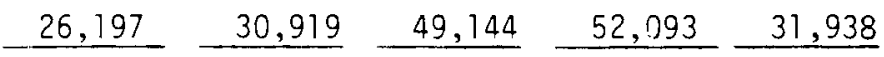

$\$ 294,008$

$\$ 347,005$

$\$ 551,543$

$\$ 584,637$

$\$ 358,439$

750

750

750

750

750

392

463

735

780

478 
TABLE 3. Performance Variables

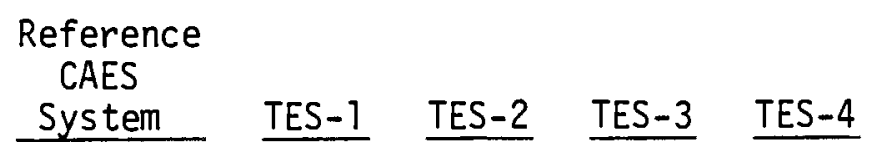

Compressor Specific Mass Flow
$(\mathrm{kg} / \mathrm{kWh}(\mathrm{in}))$
6.14
5.69
$5.43 \quad 5.79$
5.95

Turbine Specific Mass Flow

( $\mathrm{kg} / \mathrm{kWh}$ (out))

4.23

4.34

8.11

8.86

5.26

Coefficient of Performance

(kWh out/kWh in)

1.45

1.31

0.67

0.65

1.13

Turbine Heat Rate

(J/Wh)

4648

4289

0

3732

Total Air Flow Required at the

Turbine to Support $750 \mathrm{MW}$

$(106 \mathrm{~kg} / \mathrm{hr})$

3.17

3.26

6.08

6.65

3.95

\subsection{STORAGE FACILITIES}

Methods for deriving the costs of storing air, fuel and heat in the CAES systems are identified in the following paragraphs.

\subsubsection{Air Storage}

The cost of air storage for the TES systems is derived by scaling the reference system air storage cost in proportion to the air flow requirements in the TES systems. As shown in Table 3, the adiabatic systems, TES- 2 and TES- 3 , have substantially greater air flow requirements than the other systems and this contributes to greater costs in this and other cost categories.

\subsubsection{Fuel Storage}

The adiabatic systems use no fuel and thus do not need fuel storage.

\subsubsection{Thermal Storage}

The cost of thermal storage is a function of both flow rate and storage volume. A cost equation was derived taking these two factors 
into account. The equation and the costs that are covered by it are described in Appendix $B$.

\subsection{TURBOMACHINERY}

The costs for the equipment used to convert electricity into compressed air and compressed air back to electricity are identified in the paragraphs below.

\subsubsection{Intercoolers}

A1l of the systems have some intercooler capacity. The cost of an intercooler in a TES system is calculated by scaling the cost of an intercooler facing similar air temperatures and pressures in the reference system by the ratio of heat rejected. The intercooler between the TES chambers and the air reservoir is used to insure that the air reservoir never sees air temperatures above the design 1 imit which was set at $325^{\circ} \mathrm{K}\left(125^{\circ} \mathrm{F}\right)$.

\subsubsection{Aftercooler}

An aftercooler is used in the reference system and the TES-4 system. The cost of the aftercooler in the TES-4 system is derived by multiplying the reference system aftercooler cost by the ratio of the heat rejected at this point in the two systems.

\subsubsection{Compressor Recuperator}

Because there is no compressor recuperator in the reference system, the cost of the component in the TES-1 system was derived independent1y. It was calculated using standard heat exchanger costing techniques and using an overal1 heat transfer coefficient of $170.2 \mathrm{~W} / \mathrm{K} \cdot \mathrm{m}^{2}\left(30 \mathrm{Btu} / \mathrm{h} \cdot{ }^{\circ} \mathrm{F} \cdot \mathrm{ft}^{2}\right)$.

\subsubsection{Compressors}

The cost of a compressor in a TES system is calculated by multiplying the reference system compressor cost by the ratio of the coefficient of performance as defined in Table 3. This takes into account the size difference resulting from the difference in both the turbine specific mass flow and the compressor specific mass flow. It does not account 
for any increase in capital cost that might be required for a compressor operating at the higher temperatures present in the TES-2 system. The impact of this capital cost uncertainty is treated in the sensitivity analysis section.

\subsubsection{Auxillary Compressor Motor}

The drive for the compressors in the CAES systems is the motor/generator system. This has a capacity equal to the output of the CAES system, $750 \mathrm{MW}$. When the coefficient of performance is greater than 1.0, the electrical generator producing the output is large enough to drive for the compressors when it is connected as an electric motor. When the coefficient of performance is less than 1.0, the generator is not large enough to provide all of the compressor drive capacity necessary. The presence, and therefore a cost for the auxillary compressor motors in the adiabatic systems is a result of the coefficients of performance being less than 1.0 .

\subsubsection{Motor/Generator}

This item is the same for a 11 CAES systems.

\subsubsection{Turbines}

The cost of the turbines is based on the turbine specific mass flow for each system. The electrical output of each of these systems is assumed to be $750 \mathrm{MW}$. It is assumed that the turbine producing the output will vary in size and cost in relation to the air flow required as indicated by the turbine specific mass flow requirement.

\subsubsection{Turbine Exhaust Recuperator}

A turbine exhaust recuperator is used in the reference, TES-1 and TES-4 systems. The cost of this component in the TES systems is calculated by multiplying the reference system cost by both the ratio of the heat transferred and the ratio of the log-mean temperature difference across the heat exchangers in the two systems being compared (see Appendix A). 


\subsubsection{Other Turbomachinery}

The cost of this category is lower in the adiabatic systems by an amount equal to the cost of the high pressure turbine combustor that is not required in these systems.

In this category are included all the turbomachinery components itemized in the Acres America (Hobson et al. 1978) capital cost tables under turbomachinery and not listed separately above. Such items as turbomachinery platforms and water ways, starting motors, clutches and air filters are included here. The cost of these components is not expected to be greatly different among the systems.

\subsection{ELECTRICAL AND MISCELLANEOUS}

In the electrical category is included a 11 the switchyard equipment. The miscellaneous equipment category includes meteorological, communications, alarm, animal control and some maintenance systems. A1l of this equipment is assumed to cost the same for all CAES systems.

\subsection{INDIRECT COSTS}

Costs for engineering and miscellaneous and contingency are a function of direct costs. The same factors are used in a 11 the CAES systems. Escalation is based on a $6 \%$ per year escalation rate and interest during construction on a $10 \%$ per year cost of money. A $5 \%$ per year escalation rate and a $12 \%$ cost of money were used in the Acres America study (Hobson et a1. 1978, p. 8-29, Table 8-23).

\subsection{TOTAL INSTALLED COST}

The reference system has the lowest installed cost of all the CAES systems. The hybrid systems are moderately more expensive. The adiabatic systems are nearly twice as costiy as the reference system. The price levels are beginning-of-year 1985 dollars, the assumed first year of operation of these systems. 


\subsection{THE LEVELIZED COST OF ELECTRICITY}

The method used here to calculate the levelized cost of electricity is a levelized revenue requirements approach as is recommended in the EPRI TAG. The base year for all price levels and present value calculations is 1985. The assumptions used in the levelized cost calculations that follow are described below.

\subsection{BASE CASE ASSUMPTIONS}

The assumptions used to calculate the levelized cost of electricity listed in Table 4 were obtained from two sources. The plant size, life and storage capacity are base design specifications in the CAES system in the Acres America study (Hobson et a1. 1978, pp. 8-29) and are used here for the reference CAES system.

The $0 \& M$ costs and compression energy cost were also taken from that study. The same $0 \& M$ costs are used for the CAES systems and the GT system. There is a wide range of $0 \& M$ costs reported in the literature for gas turbine systems on various bases of operation. Some are higher and some are lower than those shown in Table 4. The actual difference in $0 \& M$ costs between the systems in this paper will probably be small relative to the total costs of electricity reported. The difference is neglected here because of these considerations.

The remaining values listed were obtained from the EPRI TAG. The fuel cost is that for No. 2011 in 1985. The cost reported in the TAG was $\$ 3.11 / \mathrm{GJ}\left(\$ 3.28 / 10^{6} \mathrm{Btu}\right)$ for 1985 in end-of-year (EOY) 1977 dollars (EPRI 1978, $\mathrm{p}_{\mathrm{j}} \mathrm{X}-8$ ). In terms used in the TAG, this cost included "real escalation" (a) but not "inflation" from EOY 1977 to the beginning of 1985 (EPRI 1978, pp. $X-1, X-10$ ). Thus, this cost had to be inflated $6 \%$ per year to arrive at the 1985 price level shown in the table. The TAG fuel cost appears low in light of recent developments in the oil market. The impact of these developments will be discussed in the sensitivity analysis section.

(a) see discussion on escalation below 
TABLE 4. Base Case Economic Assumptions

Parameter

Plant Size

Plant Life

Storage Capacity

Operation and Maintenance Cost

Fixed

Variable

Compression Energy Cost

Turbine Fuel Cost

Cost of Money

Fixed Charge Rate

Escalation Rates:

Capita 1

$0 \& M$

Turbine Fuel

Compression Energy

Gas Turbine Parameters

Capital Cost

Turbine Heat Rate
Value

$750 \mathrm{MW}$

35 years

20 hours

$\$ 4.85 / \mathrm{kW}$

$.32 \mathrm{mills} / \mathrm{kWh}$

$30 \mathrm{mills} / \mathrm{kWh}$

$\$ 4.74 / \mathrm{GJ}\left(\$ 5.00 / 10^{6} \mathrm{Btu}\right)$

$10 \% / \mathrm{yr}$

$15 \% / \mathrm{yr}$

$6 \% / y r$

$6 \% / y r$

$7 \% / y r$

$7 \% / \mathrm{yr}$

$\$ 240 / \mathrm{kW}$

$12,133 \mathrm{~J} / \mathrm{Wh}(11,500 \mathrm{Btu} / \mathrm{kWh})$ 
The cost of money and fixed charge rate are those suggested in the TAG (EPRI 1978, pp. V-4, 5). The cost of money is made up to two components, the "real" cost of money, $3.8 \%$ per year, and the "inflation" rate, $6 \%$ per year. The cost of money is the product of these two factors, 1.038 $\star 1.06=1.10$, or $10 \%$ per year (EPRI 1978, p. V-11).

The "apparent" escalation rate is the product of the "real" escalation rate (the cost increases due to resource depletion and demand increases) and the "inflation" rate (EPRI 1978, p. V-11). For fuel costs, the "real" escalation rate is non-zero and varies over time (EPRI 1978, p. XI-8)。 The rate taken from the TAG as an approximate average for this study period is . $9 \%$ per year. Thus, the "apparent" escalation rate for fuel and compression energy (fuel related) costs is $1.09 * 1.06=1.07$, or $7 \%$ per year.

The two parameters shown for the GT system were also obtained from the TAG. These estimates are for an advanced design GT system which is expected to be available for commercial operation in 1985. The most likely capital cost was reported in the TAG as $\$ 160 / \mathrm{kW}$ in EOY 1977 dollars (EPRI 1978, p. XII-23). It was escalated at $6 \%$ per year to arrive at the 1985 price level shown. The heat rate used is the average annual heat rate, which takes into account some cycling inefficiencies.

\subsection{LEVELIZED COSTS}

Table 5 presents the levelized costs for all systems. The levelized cost of electricity for the reference CAES system is $129.7 \mathrm{mills} / \mathrm{kWh}$. To arrive at this value, the cumulative present value of the costs for each category is calculated over the 35 years of operation. The total is then converted to a levelized annual cost. To arrive at the unit cost in mills/kWh, the levelized annual cost for each category is divided by the total annual production. The same procedure is used to calculate the costs for the other systems.

The calculations for the levelized costs in Table 5 are provided in Appendix $C$. The reader will note that the calculation for the levelized 
TABLE 5. The Levelized Cost of Electricity (mil1s/kWh in 1985)

\begin{tabular}{|c|c|c|c|c|c|c|}
\hline Component & $\begin{array}{l}\text { Reference } \\
\text { System } \\
\end{array}$ & TES-1 & TES-2 & TES-3 & TES-4 & $\underline{G T}$ \\
\hline Capital & 26.8 & 31.7 & 50.3 & 53.4 & 32.7 & 16.4 \\
\hline $0 \& M$ & 5.0 & 5.0 & 5.0 & -5.0 & 5.0 & 5.0 \\
\hline Turbine Fue 1 & 50.5 & 46.6 & - & - & 40.5 & 131.7 \\
\hline Compression Energy & 47.4 & 52.4 & 102.5 & 105.7 & 60.8 & 二 \\
\hline Total & 129.7 & 135.7 & 157.8 & 164.1 & 139.0 & 153.1 \\
\hline
\end{tabular}

capital cost differs from those for 0 \& $M$, turbine fuel and compression energy: the capital cost calculations do not include a provision for future escalation. The levelized capital cost component covers investments that have been made by the time system operation conmences. No further payments are made. The other components, 0 \& M, turbine fuel and compression energy costs will be paid during each year of operation using current dollars which will include the escalation to the time of payment. When the levelized cost of these payments is calculated, this escalation must be taken into account as it is in Appendix $C$.

The reference system has the lowest cost of all the systems under the base case conditions 1 isted in Table 4. The hybrid systems, TES-1 and TES-4, are moderately more expensive than the reference system. They have slightiy higher capital costs and use more compression energy but use less turbine fuel. The adiabatic systems are the most expensive systems. They use no turbine fuel but have much higher capital and compression energy costs. In the GT system, the turbine supplies the energy for both compressing the air and providing the electrical output. This results in a much larger cost for turbine fuel. Although the GT system has a lower capital cost and no separate compression energy cost, the larger fuel consumption results in a total cost much larger than the reference system. 


\subsection{INCREMENTAL LEVELIZED COST OF ELECTRICITY}

The relative cost rankings of the comparison system change when some of the base case parametric values are changed in the sensitivity analysis section. These changes are measured as variations in the incremental levelized cost of electricity. The incremental cost is the amount by which the system cost under consideration differs from the cost of the reference system (see Table 6). The incremental cost is negative if the test system costs less to operate than the reference system under the test conditions and positive if the cost of the test system is greater under those conditions. Under the base case conditions, the reference system costs less to operate than all the others so all of the incremental levelized costs are positive in Table 6.

TABLE 6. Incremental Levelized Costs of Electricity for the Base Case (mills/kWh in 1985)

System

Reference System

TES- 1

TES-2

TES-3

TES-4

GT
Levelized Cost of Electricity

129.7

135.7

157.8

164.1

139.0

153.1
Incrementa 1 Levelized Cost of Electricity

0.0

6.0

28.1

34.4

9.3

23.4 



\subsection{SENSITIVITY ANALYSIS}

The base case assumptions in Table 4 are the foundation for the incremental levelized costs of electricity in Table 6 . Those assumptions represent one set of conditions out of the many possible sets that the operator of a peaking/storage system might face. A variation from the value assumed for a critical parameter may occur for a number of reasons for a given utility and may result in a significant change in the incremental cost.

With these considerations in mind, the values of three critical parameters -- capacity factor, turbine fuel cost and compression energy cost -.- are varied over a range of values in this section. The changes in incremental levelized cost are tabulated for two cases: 1) using 30 mills/kWh as the 1985 compression energy cost shown in Table 7A; and 2) using $20 \mathrm{mills} / \mathrm{kWh}$ as the 1985 compression energy cost shown in Table 7B. Two compression energy costs are used because the cost of excess base load electricity varies with individual utility circumstances. Using two compression energy costs broadens the applicability of the sensitivity analysis.

\subsection{CAPACITY FACTOR}

The number of hours per year that a particular peaking system will be operated depends on several factors. One important factor which varies from utility to utility, is the shape of the daily load curve in relation to the base load capacity. One utility may not need more than 4 hours of peaking generation a day and another may, in the short term, need more than 8 hours a day.

Capacity factor is a measure of the number of hours a year the system generates electricity and is usually given as a percent of the total hours in a year. The CAES systems are assumed to generate 8 hours a day 5 days a week which results in a capacity factor near 25\% (note the circles identifying the base case in Figure $6 \mathrm{~A}$ ). 
TABLE 7A. The Results of the Sensitivity Analysis Using $30 \mathrm{mills} / \mathrm{kWh}$ Compression Energy Cost (mil1 s/kWh in 1985)

$\underline{T E S-1} \underline{T E S-2} \underline{T E S-3} \quad \underline{T E S-4} \quad \underline{\text { GT }}$

Reference

Conditions

$\begin{array}{lllll}6.0 & 28.1 & 34.4 & 9.3 & 23.4\end{array}$

Capacity Factor

$\begin{array}{rrrrrr}10 \% & 13.3 & 63.1 & 74.3 & 18.2 & 7.8 \\ 15 \% & 9.3 & 43.8 & 52.1 & 13.2 & 16.5 \\ 20 \% & 7.2 & 34.0 & 41.7 & 10.8 & 20.8 \\ 25 \% & 6.0 & 28.7 & 34.4 & 9.3 & 23.4 \\ 30 \% & 5.3 & 24.2 & 30.0 & 8.3 & 25.7 \\ 35 \% & 4.7 & 27.4 & 26.8 & 7.6 & 26.4\end{array}$

Turbine Fuel Cost

\begin{tabular}{|c|c|c|c|c|c|c|c|}
\hline$/ G J^{(a)}$ & $\$ / 10^{6} \mathrm{Btu}^{(\mathrm{a})}$ & $\%(b)$ & & & & & \\
\hline $\begin{array}{l}7.00 \\
4.50 \\
5.00 \\
5.50 \\
5.00\end{array}$ & $\begin{array}{l}4.22 \\
4.75 \\
5.28 \\
5.80 \\
6.33 \\
6.86\end{array}$ & $\begin{array}{l}5.8 \\
6.6 \\
7.4 \\
8.0 \\
8.6 \\
9.1\end{array}$ & $\begin{array}{l}6.6 \\
6.2 \\
5.8 \\
5.4 \\
5.0 \\
4.6\end{array}$ & $\begin{array}{r}36.0 \\
30.7 \\
25.3 \\
20.0 \\
14.7 \\
9.3\end{array}$ & $\begin{array}{l}42.3 \\
37.0 \\
31.6 \\
26.3 \\
21.0 \\
15.6\end{array}$ & $\begin{array}{r}10.9 \\
9.8 \\
8.8 \\
7.7 \\
6.6 \\
5.6\end{array}$ & $\begin{array}{l}10.7 \\
19.3 \\
27.9 \\
36.4 \\
45.0 \\
53.6\end{array}$ \\
\hline
\end{tabular}

Compression Energy

Cost (milis/kWh)

$\begin{array}{rrrrrr}10 & 2.7 & -8.6 & -4.5 & .4 & 55.0 \\ 20 & 4.3 & 9.7 & 15.0 & 4.8 & 39.2 \\ 30 & 6.0 & 28.7 & 34.4 & 9.3 & 23.4 \\ 40 & 7.7 & 46.5 & 53.8 & 13.8 & 7.6 \\ 50 & 9.3 & 64.8 & 73.2 & 18.3 & -8.2 \\ 60 & 10.9 & 83.2 & 92.6 & 22.8 & -24.0\end{array}$

\footnotetext{
(a) This 1985 fuel cost is assumed to escalate $7 \%$ per year from 1985 on.

(b) Assuming a beginning 1985 fuel cost of $\$ 4.74 / \mathrm{GJ}(\$ 5.00 / 106 \mathrm{Btu})$ this is the fuel cost escalation rate from 1985 on.
} 
TABLE 7B. The Results of the Sensitivity Analysis Usina $20 \mathrm{mills} / \mathrm{k}$ th Compression Energy Cost (mills/kWh in 1985)

\section{$\underline{T E S-1} \quad \underline{T E S-2} \quad \underline{T E S-3} \quad \underline{T E S-4} \quad \underline{\text { GT }}$}

Reference

Conditions

$\begin{array}{lllll}4.3 & 9.7 & 15.0 & 4.8 & 39.2\end{array}$

Capacity Factor

$\begin{array}{rrrrrr}10 \% & 11.6 & 44.7 & 54.9 & 13.7 & 23.6 \\ 15 \% & 7.6 & 25.4 & 32.7 & 8.7 & 32.3 \\ 20 \% & 5.5 & 15.6 & 21.7 & 6.3 & 36.6 \\ 25 \% & 4.3 & 9.7 & 15.0 & 4.8 & 39.2 \\ 30 \% & 3.6 & 5.8 & 10.6 & 3.8 & 40.9 \\ 35 \% & 3.0 & 3.0 & 7.4 & 3.1 & 42.2\end{array}$

Turbine Fuel Cost

\begin{tabular}{|c|c|c|c|c|c|c|c|}
\hline$G J(a)$ & $\$ / 10^{6} \mathrm{Btu}^{(\mathrm{a})}$ & $\%^{(b)}$ & & & & & \\
\hline $\begin{array}{l}4.00 \\
4.50 \\
5.00 \\
5.50 \\
6.00 \\
6.50\end{array}$ & $\begin{array}{l}4.22 \\
4.75 \\
5.28 \\
5.80 \\
6.33 \\
6.86\end{array}$ & $\begin{array}{l}5.8 \\
6.6 \\
7.4 \\
8.0 \\
8.6 \\
9.1\end{array}$ & $\begin{array}{l}4.9 \\
4.5 \\
4.1 \\
3.7 \\
3.3 \\
2.9\end{array}$ & $\begin{array}{r}17.6 \\
12.3 \\
6.9 \\
1.6 \\
-3.7 \\
-9.1\end{array}$ & $\begin{array}{r}22.9 \\
17.6 \\
12.2 \\
6.9 \\
1.6 \\
-3.8\end{array}$ & $\begin{array}{l}6.9 \\
5.3 \\
4.3 \\
3.2 \\
2.1 \\
1.1\end{array}$ & $\begin{array}{l}26.5 \\
35.1 \\
43.7 \\
52.2 \\
60.8 \\
69.4\end{array}$ \\
\hline
\end{tabular}

Compression Energy

Cost (mills/kWh)

$\begin{array}{rrrrrr}10 & 2.7 & -8.6 & -4.5 & .4 & 55.0 \\ 20 & 4.3 & 9.7 & 15.0 & 4.8 & 39.2 \\ 30 & 6.0 & 28.1 & 34.4 & 9.3 & 23.4 \\ 40 & 7.7 & 46.5 & 53.8 & 13.8 & 7.6 \\ 50 & 9.3 & 64.8 & 73.2 & 18.3 & -8.2 \\ 60 & 10.9 & 83.2 & 92.6 & 22.8 & -24.0\end{array}$

\footnotetext{
(a) This 1985 fuel cost is assumed to escalate $7 \%$ per year from 1985 on. Assuming a beginning 1985 fuel cost of $\$ 4.74 / G J\left(\$ 5.00 / 10^{6}\right.$ Btu), this is the fuel cost escalation rate from 1985 on.
} 


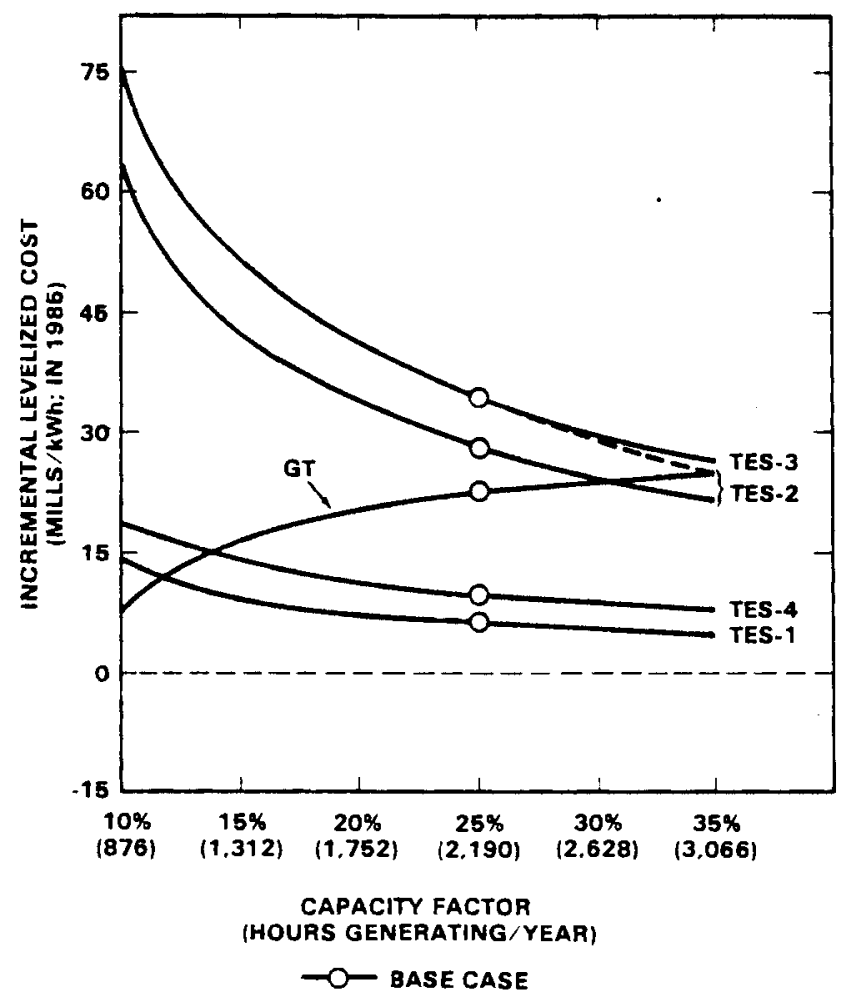

FIGURE 6A. Sensitivity to Changes in Capacity Factor Using 30 Milis/kWh Compression Energy Cost

The incremental costs of the TES systems decrease with increasing capacity factor because the capital cost in those systems is greater than the reference system capital cost (see Figure 6A). Increasing the capacity factor spreads the fixed capital charges over more units of production and thus reduces the capital portion of the per unit cost of electricity. The impact is greater on systems with higher capital costs.

The capital cost estimates for all the systems carry with them some uncertainties. A specific uncertainty, discussed earlier, is the cost of the compressors operating at the higher temperatures in the TES-2 system. To obtain an idea of the impact of this uncertainty we can compare the TES-2 curve in Figure $6 \mathrm{~A}$ to the dashed curve in that figure. If the higher temperature compressor costs $77 \%$ more than a conventional 
compressor, the TES-2 curve would shift to the position of the dashed curve and would cross the TES-3 curve near the $25 \%$ capacity factor. The dashed curve is slightly more sensitive to changes in capacity factor because of the relatively higher capital cost it represents.

In the GT system, the incremental cost increases with increasing capacity factors. In this system, the capital cost is lower than the reference system capital cost. When system use increases, the reference system's per unit capital cost decreases faster than the GT system per unit capital cost. Thus, CAES systems are more competitive with GT systems at higher capacity factors.

When compression energy cost is lowered, the incremental levelized cost of the TES systems is lower, but still positive, for all capacity factors. This is illustrated in Figure 6B. Since the TES systems use more compression energy, a reduction in the cost of that component of total energy cost benefits those systems more than the reference system.

The reverse is true for the GT system incremental cost. That system does not use electricity to power the compressors. The CAES systems will be more competitive with lower compression energy costs.

\subsection{TURBINE FUEL COST}

The uncertainty surrounding the future price and availability of oil for electricity generation is being actively discussed in utility power planning departments. The planners are looking for generation technologies that mitigate the impact of the uncertainties. The CAES concepts in this report are among the new technologies being considered for future generation. To present a more complete evaluation of the worth of these concepts, they are evaluated over a range of future fuel prices.

The base case fuel cost of $\$ 4.74 / G J\left(\$ 5.00 / 10^{6}\right.$ BTU) in 1985 price levels was taken from the EPRI TAG which was published in 1978. The heat content of a gallon of no. $20 i 1$ is approximately 141,000 BTU which makes this 1985 price equivalent to about $71 \% / g a 1$. Because of recent developments in the world oil market, the price for no. 20 il in 1979 


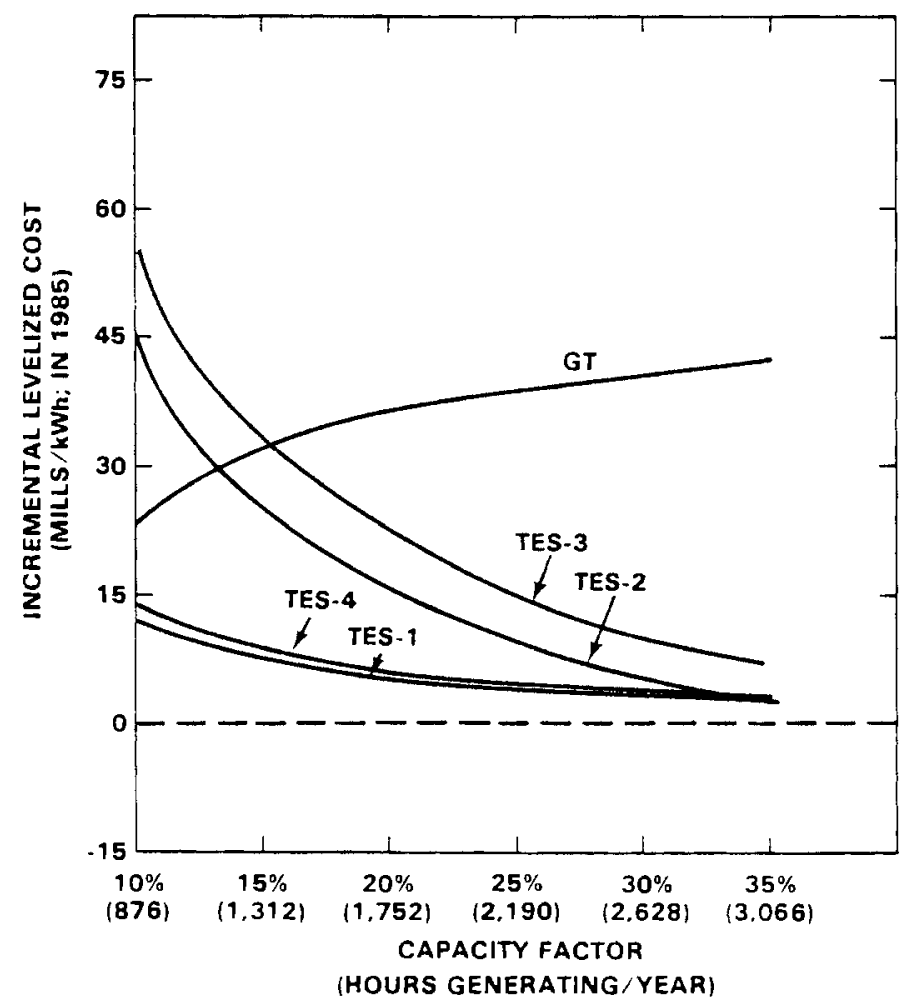

FIGURE 6B. Sensitivity to Changes in Capacity Factor Using $20 \mathrm{Mi} 1 \mathrm{ls} / \mathrm{kWh}$ Compression Energy Cost

has been above $80 \$ / g a l$. It is expected that the long run oil price will escalate from the high levels established this year. Thus, the base case fuel cost in this study is low. The impact of higher costs is examined in the analyses in this section.

When a $30 \mathrm{mills} / \mathrm{kWh}$ compression energy cost is used, all of the TES systems cost more to operate (all have a positive incremental levelized cost) for the range of fuel costs examined. This relationship is shown in Figure $7 \mathrm{~A}$. The fuel costs shown on the horizontal axis are 1985 fuel costs and are assumed to escalate at $7 \%$ per year over the 35 year operating life of the systems. If a 1985 fuel price of $\$ 4.74 / \mathrm{GJ}\left(\$ 5.00 / 10^{6} \mathrm{Btu}\right)$ is assumed and the fuel cost escalation rate is varied, the bottom scale applies. 


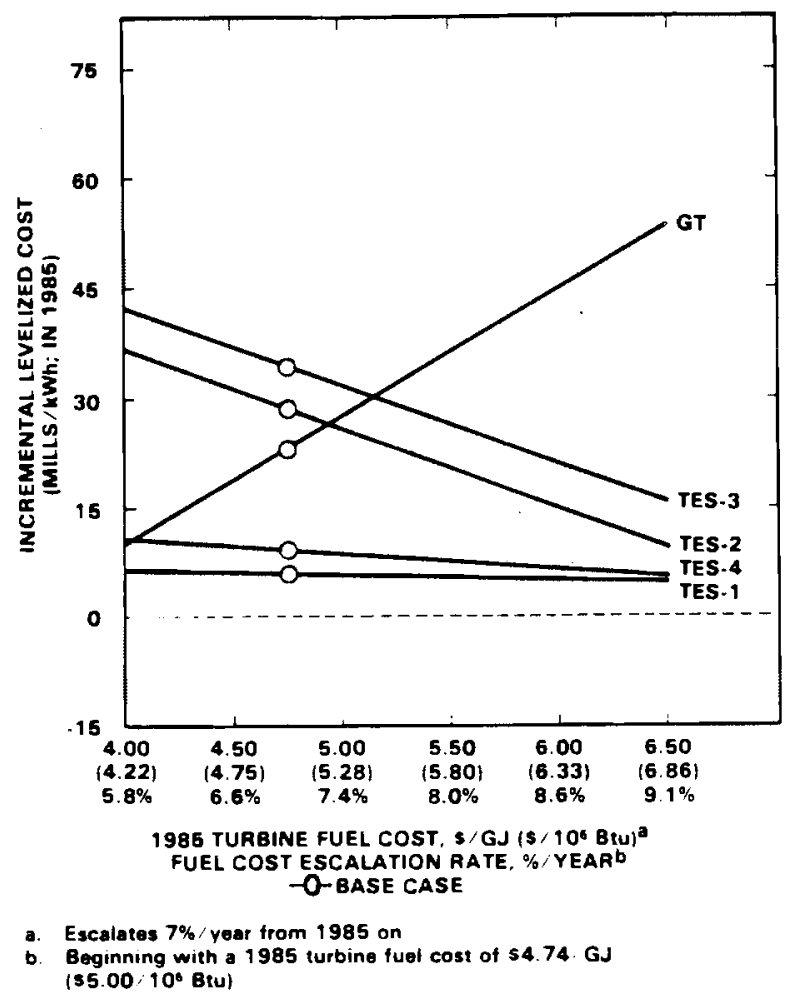

FIGURE 7A. Sensitivity to Changes in Turbine Fuel cost and Fuel Cost Escalation Using $30 \mathrm{Mills} / \mathrm{kWh}$ Compression Energy Cost

The adiabatic systems, TES-2 and TES-3, are more sensitive to changes in fuel cost than are the hybrid systems because the adiabatic systems present the greater variance in fuel use. This can be seen by comparing the turbine heat rates in Table 3 . The adiabatic heat rates are zero so the variance from the reference system is equal to the full reference system fuel use. However, the greatest variance in fuel use from the reference CAES system is found in the GT system. Since the turbine supplies the energy to drive the compressors as well as provide the electrical output, it uses about 3 times as much fuel as is used in the reference system. This is shown by comparing the GT heat rate in Table 4 to the reference system heat rate in Table 3 . When the fuel 
costs rise, the GT levelized fuel cost rises more rapidly than the other systems.

If compression energy cost is lowered to $20 \mathrm{mi} 11 \mathrm{~s} / \mathrm{kWh}$, the incremental levelized costs of the adiabatic systems become negative for some 1985 fuel costs. This is shown in Figure 7B. The levelized cost of the TES2 system is negative above 1985 fuel costs of about $\$ 5.62 / G J\left(\$ 5.93 / 10^{6}\right.$ Btu) and the TES-3 cost is negative above $\$ 6.12 / \mathrm{GJ}\left(\$ 6.46 / 10^{6} \mathrm{Btu}\right)$.

\subsection{COMPRESSION ENERGY}

The cost that a utility charges itself for using excess baseload electricity in CAES systems will likely be the incremental cost of operating its base load units. The fuel costs and other variable costs

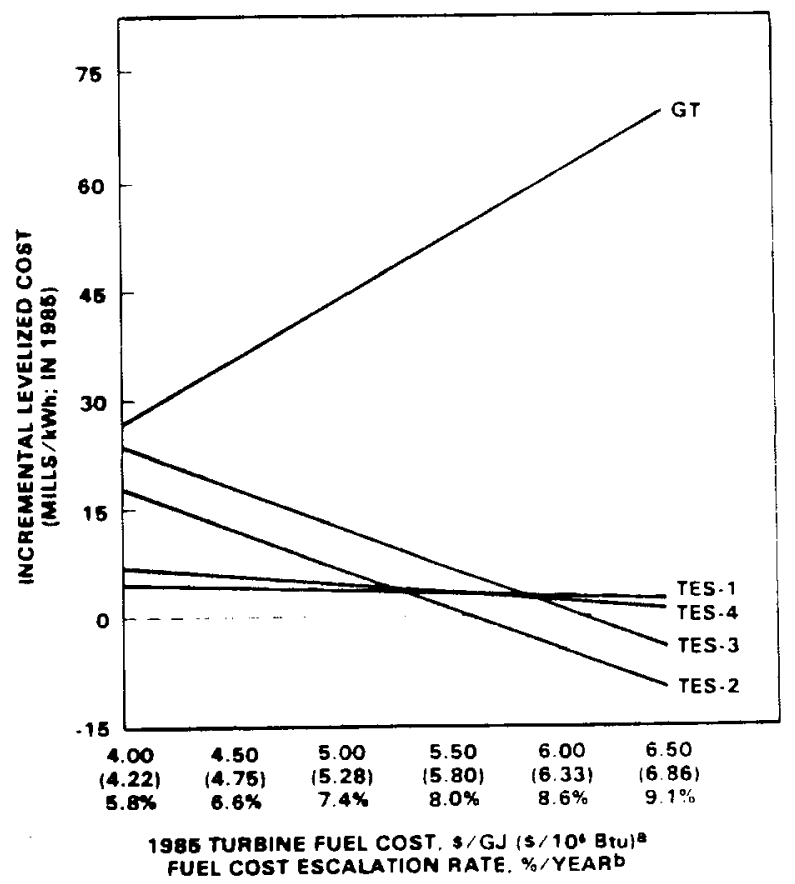

- Excaletes $7 \% /$ yeer from 1985 on

Becinning with 1986 turbine fual cost of $\$ 4.74 / \mathrm{GJ}$

$(\$ 6.00 / 10 * \mathrm{Btu})$

FIGURE 78. Sensitivity to Changes in Turbine Fuel Cost and Fuel Cost Escalation Using $20 \mathrm{Mills} / \mathrm{kWh}$ Compression Energy Cost 
will show as operating expenses and no other costs will appear. This incremental operating cost will vary depending on the type of unit. One recent study puts nuclear at the $10 \mathrm{w}$ end of the spectrum at $7 \mathrm{mills} / \mathrm{kWh}$ and oil-fired at the high end, at over $50 \mathrm{mills} / \mathrm{kWh}$ (Hobson et al. 1978 pp. 8-41, 44). This data was used in setting the range of values to be considered.

As shown in Figure 8 , the adiabatic systems exhibit the highest level of sensitivity of the TES systems. They have the largest incremental cost components due to compression energy cost. The GT system also is very sensitive to compression energy cost changes. With other base case assumptions held constant, the GT system is less expensive to operate than the reference system above a compression energy cost of about 45 $\mathrm{mi} 11 \mathrm{~s} / \mathrm{kWh}$.

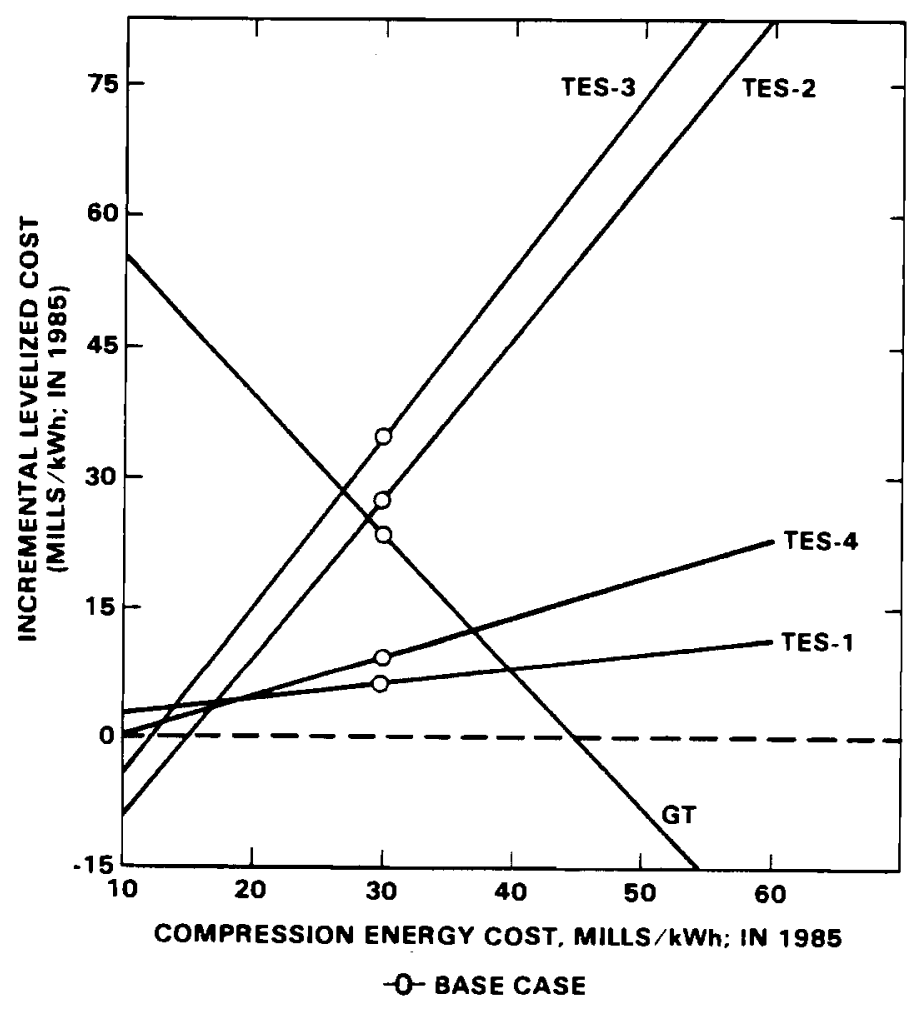

FIGURE 8. Sensitivity to Changes in Compression Energy Cost 


\section{REFERENCES}

Electric Power Research Institute, Technical Assessment Guide. EPRI PS-866-SR, Electric Power Research Institute, Palo Alto, CA, 1978.

Hobson, M.J. et al., Feasibility of Compressed Air Storage as a Peak Shaving Technique in California. Prepared for the California Energy Commission by Acres America, Buffalo, New York, 1978. 
APPENDIX A 



\title{
THERMODYNAMIC ANALYSIS OF THE CAES CYCLES
}

\author{
G. DeHaan, PNL
}

The CAES cycles in this report were thermodynamically analyzed with the help of a computer code called CYCLOPS-MOD1. (a) A brief description of the code is provided here along with an explanation of the three output tables. Some of the thermodynamic cycle data output is provided in Tables A-1 through A-5 for use in the report.

CYCLOPS-MOD 1 is a FORTRAN code written for an IBM 7094 computer (Hessler et a7. 1964). It was written to perform design point thermodynamic cycle calculations of systems comprising pumps, turbines, compressors, heat exchangers, phase separators, and flow mixing, splitting, and throttling devices. It was capable of handling water/steam, air nitrogen, and parahydrogen working fluids. The modular form of the code allowed any combination of components to be treated and logic was incorporated to allow parameterization of cycle configurations.

A copy of the original version was obtained from the Argonne Code Center and converted to the UNIVAC system for use in analyzing advanced concepts in the Compressed Air Energy Storage Program at PNL. When the code was received from ACC the steam properties were missing. So, ASME water/steam properties were added. Numerous modifications have since been made to the code that simplify its usage as well as greatly expand its capabilities. Improvements incorporated for the user include a shorter, more concise input, more simplified parameterization capabilities, and various output options which allow more flexibility in interpreting results. Expanded code capabilities include the addition of treating fluidized bed combustors, ideal and fueled combustors, and a simplified gasifier. A fluid property approximation has also been added to handle combustion products that result from the fuel combustors or gasifier.

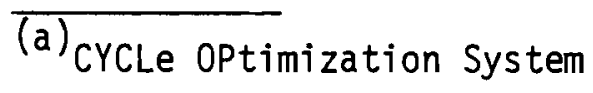


TABLE A-1. Reference CAES System Thermodynamic Cycle Data

\begin{tabular}{|c|c|}
\hline Station & $\begin{array}{c}\text { Pressure } \\
\mathrm{MPa} \\
\end{array}$ \\
\hline 1 & 0.101 \\
\hline 2 & 0.422 \\
\hline 3 & 0.414 \\
\hline 4 & 1.724 \\
\hline 6 & 1.689 \\
\hline 7 & 7.038 \\
\hline 8 & 6.897 \\
\hline 11 & 6.688 \\
\hline 12 & 6.554 \\
\hline 13 & 6.423 \\
\hline 14 & 1.285 \\
\hline 15 & 1.259 \\
\hline 16 & 0.103 \\
\hline 17 & 0.101 \\
\hline
\end{tabular}

\begin{tabular}{ccc}
$\begin{array}{c}\text { Temperature } \\
{ }^{\mathrm{K}} \mathrm{N}\end{array}$ & & $\begin{array}{c}\text { Enthalpy } \\
\mathrm{J}\end{array}$ \\
\cline { 1 - 1 } 299.82 & & 136.01 \\
476.14 & & 217.76 \\
324.82 & & 147.24 \\
514.65 & & 234.76 \\
324.82 & & 146.23 \\
513.47 & & 233.18 \\
324.82 & & 142.60 \\
324.61 & & 142.60 \\
583.26 & & 266.80 \\
812.01 & & 379.67 \\
571.97 & & 261.94 \\
1089.28 & 521.49 \\
647.93 & 298.43 \\
433.80 & 197.51
\end{tabular}


TABLE A-2. TES-1 System Thermodynamic Cycle Data

\begin{tabular}{cc} 
Station & $\begin{array}{l}\text { Pressure } \\
\text { MPa }\end{array}$ \\
\cline { 2 - 3 } 1 & 0.101 \\
2 & 0.431 \\
3 & 0.422 \\
4 & 1.926 \\
5 & 1.887 \\
6 & 1.850 \\
7 & 7.329 \\
8 & 7.183 \\
18 & 7.039 \\
9 & 6.898 \\
10 & 6.688 \\
11 & 6.554 \\
12 & 6.423 \\
13 & 1.071 \\
14 & 1.049 \\
15 & 1.028 \\
16 & 0.103 \\
17 & 0.101
\end{tabular}

\begin{tabular}{ccc}
$\begin{array}{c}\text { Temperature } \\
{ }^{\circ} \mathrm{K}\end{array}$ & & $\begin{array}{c}\text { Enthalpy } \\
\mathrm{J}\end{array}$ \\
\cline { 1 - 1 } 299.82 & & 136.06 \\
479.12 & & 218.45 \\
380.56 & & 172.86 \\
616.47 & & 283.14 \\
527.69 & & 240.90 \\
324.82 & & 146.12 \\
505.49 & & 229.31 \\
593.28 & & 271.56 \\
338.10 & & 149.02 \\
324.82 & & 142.60 \\
324.61 & & 142.60 \\
579.89 & & 265.13 \\
811.93 & 379.63 \\
549.94 & 251.53 \\
649.90 & 299.28 \\
1089.61 & 521.59 \\
674.89 & 311.51 \\
587.48 & 296.46
\end{tabular}


TABLE A-3. TES-2 System Thermodynamic Cycle Data

$\begin{array}{cc}\text { Station } & \begin{array}{c}\text { Pressure } \\ \text { MPa }\end{array} \\ 1 & 0.101 \\ 2 & 1.531 \\ 3 & 1.501 \\ 4 & 7.178 \\ 8 & 7.034 \\ 9 & 6.893 \\ 10 & 6.688 \\ 11 & 6.554 \\ 13 & 0.591 \\ 15 & 0.579 \\ 16 & 0.101\end{array}$

$\begin{array}{ccc}\begin{array}{c}\text { Temperature } \\ { }^{\circ} \mathrm{K}\end{array} & & \begin{array}{c}\text { Enthalpy } \\ \mathrm{J}\end{array} \\ 299.82 & & 136.06 \\ 699.77 & & 323.70 \\ 338.71 & & 152.83 \\ 557.61 & & 254.34 \\ 336.27 & & 148.13 \\ 324.82 & & 142.60 \\ 324.61 & & 142.60 \\ 545.96 & & 248.81 \\ 316.95 & & 143.46 \\ 680.66 & & 314.33 \\ 460.55 & & 209.93\end{array}$


TABLE A-4. TES-3 System Thermodynamic Cycle Data

\begin{tabular}{cc} 
Station & $\begin{array}{c}\text { Pressure } \\
\mathrm{MPa}\end{array}$ \\
\cline { 3 - 3 } 1 & 0.101 \\
2 & 0.991 \\
3 & 0.971 \\
4 & 2.427 \\
5 & 2.378 \\
6 & 7.177 \\
8 & 7.034 \\
9 & 6.893 \\
10 & 6.688 \\
11 & 6.554 \\
13 & 1.026 \\
15 & 1.006 \\
16 & 0.101
\end{tabular}

\begin{tabular}{ccc}
$\begin{array}{c}\text { Temperature } \\
{ }_{\mathrm{K}}\end{array}$ & & $\begin{array}{c}\text { Entha]py } \\
\mathrm{J}\end{array}$ \\
\cline { 1 - 1 } 299.82 & & 136.06 \\
616.49 & & 283.23 \\
338.71 & & 153.21 \\
456.80 & & 207.38 \\
354.35 & & 159.55 \\
505.37 & & 229.28 \\
333.66 & & 146.86 \\
324.82 & & 142.60 \\
324.62 & & 142.60 \\
496.27 & & 225.03 \\
323.57 & & 146.15 \\
601.77 & & 276.18 \\
359.10 & & 163.20
\end{tabular}


TABLE A-5. TES-4 System Thermodynamic Cycle Data

\begin{tabular}{c} 
Station \\
\hline 1 \\
2 \\
3 \\
5 \\
6 \\
7 \\
8 \\
9 \\
10 \\
13 \\
14 \\
15 \\
16 \\
17
\end{tabular}

\begin{tabular}{c}
$\begin{array}{c}\text { Pressure } \\
\mathrm{MPa}\end{array}$ \\
\hline 0.101 \\
0.991 \\
0.971 \\
2.468 \\
2.418 \\
7.040 \\
6.899 \\
6.588 \\
6.554 \\
1.229 \\
1.204 \\
1.180 \\
0.103 \\
0.101
\end{tabular}

\begin{tabular}{c}
$\begin{array}{c}\text { Temperature } \\
{ }^{\mathrm{K}} \mathrm{C}\end{array}$ \\
\hline 299.82 \\
616.49 \\
338.71 \\
459.21 \\
324.82 \\
459.17 \\
324.82 \\
324.61 \\
477.60 \\
323.90 \\
601.79 \\
1089.61 \\
656.52 \\
521.91
\end{tabular}

$\frac{\substack{\text { Enthalpy } \\ \mathrm{J}}}{136.06}$
283.23
153.21
208.50
145.71
207.21
142.60
142.60
216.23
146.14
276.17
521.63
302.58
283.54




\section{APPENDIX A REFERENCES}

J. A. Hessler, L. R. Blue and J. L. Gumaldi, CYCLE OPTIMIZATION SYSTEM (CYCLOPS-1): An IBM Program for Heat and Mass Balance of Thermodynamic Systems. NAA-SR-9851, Atomics International, Canoga Park, CA, 1964. 

APPENDIX B 



\section{THERMAL ENERGY STORAGE UNIT COSTS}

M.K. Drost, PNL

The cost of the Therma 1 Energy Storage (TES) units in the advanced concept CAES systems is a function of both flow rate and TES volume. The relationship is different for each system and is sensitive to major changes in the thermodynamic cycles. In the equation below the parameter "a" represents the influence of flow rate on cost and parameter "b" represents the influence of volume.

$$
\text { TES } \cos t=a m=b \dot{m} t
$$

where:

a is a constant and has units of $\$ / 1 \mathrm{~b} / \mathrm{hr}$

$b$ is a constant and has units of $\$ / 1 b$

$n$ is the air mass flow rate in $1 \mathrm{~b} / \mathrm{hr}$

$t$ is the number of hours storage

The values for $a$ and $b$ for the four TES systems operating on the cycles in Appendix $A$ are given in Table $B-1$.

The cost estimate covered by the above parameters includes the following cost components:

1. The increase in shaft cost required by the addition of a TES unit.

2. The increase in duct work cost required by the addition of a TES unit.

3. The cost of the TES cavern.

4. The cost of the pebble bed containment and insulation.

5. The cost of the pebble bed media.

6. The cost of the pebble bed foundations.

The flow rate related costs were determined from previous TES shaft and duct work cost estimates according to Glendenning, which were modified to reflect only the incremental cost attributable to the TES 
TABLE B-1. TES Cost. Parameters

\begin{tabular}{lll} 
System & $\underline{\mathrm{a}}$ & $\underline{\mathrm{b}}$ \\
\hline TES-1 & .02 & .102 \\
TES-2 & .332 & .205 \\
TES-3 & .261 & .205 \\
TES-4 & .24 & 1.02
\end{tabular}

unit. The volume related cost estimates were determined by a review of previous TES cost estimates(a) (Hamilton, 1978; Hauz, et al, 1978) and standard industry cost estimating sources. Some significant unit costs would include

Pebble bed media

$\$ 15 /$ ton (Hauz, 1978)

Cavern construction cost

$\$ 172 / \mathrm{m}^{3}$ of cavern (Hauz, 1978)

Pebble bed foundations

$\$ 27 / \mathrm{m}^{3}$ of pebble bed $(\mathrm{a})$

Miscellaneous cost

$\$ 36 /$ ton of media $(a)$

(a) According to Dr. Ian Glendenning, Central Electricity Generating Board, Marchwood Engineering Laboratories, Southampton England 


\section{APPENDIX B REFERENCES}

N. I. Hamilton, "Packed Beds for Thermal Energy Storage in an Underground Compressed Air Storage System", Proceedings of Compressed Air Energy Storage Symposium, Pacific Grove, CA, May 15-18, 1978.

W. Hauz, B. J. Berkowitz and R. C. Hane, Conceptual Design of Thermal Energy Storage Systems for Near Term El ectric Utility AppTication. EPRI GE78STMP-60, GeneraT ETectric Company, Santa Barbara, CA, 1978. 
APPENDIX C 



\section{LEVELIZED REVENUE REQUIREMENTS CALCULATIONS}

The levelized cost of electricity is calculated as the levelized revenue requirement per unit of production. Because of different requirements in each category, this calculation is divided into four categories: capital, 0 \& $M$, turbine fuel, and compression energy. Calculations are shown for each system in each category.

The capital cost calculation multiplies a fixed charge rate by the installed cost and divides by the annual production. The fixed charge rate represents all the cost associated with owning a capital asset. It generally takes into account return on investment, taxes, and depreciation. No provision for inflation is included because once the investment is made, the costs to the owner do not escalate with time.

The 0 \& $M$ costs, both fixed and variable, are subject to escalation. To calculate the impact of inflation on a uniformly escalating uniform series of annual costs (as the costs for $0 \& M$, turbine fuel and compression energy are assumed to be), the formula for present worth factor shown in the calculations is used. To levelize the present worth, the factor must be multiplied by the capital recovery factor as is shown. The result is a levelizing factor for $0 \& M$ that takes into account escalation.

Turbine fuel and compression energy costs have a different levelizing factor than the one for $0 \& M$ because their cost escalation rate is different. Except for having the same levelizing factor, however, the calculations for turbine fuel and compression energy costs are different. The levelized turbine fuel cost is calculated from the 1985 fuel cost and the system turbine heat rate. The levelized compression energy cost is calculated from the 1985 compression energy cost and the system coefficient of performance. 


\section{REFERENCE CAES SYSTEM: LEVELIZED REVENUE REQUIREMENT}

Capital:

$$
\begin{aligned}
\text { Levelized Capital Cost } & =\frac{\$ / \mathrm{kW} * \text { Fixed Charge Rate } * 1000}{\text { Generatina Hours/Year }} \\
& =\frac{392 * .15 * 1000}{.25 * 8760} \\
& =26 \mathrm{mi} 1 \mathrm{~s} / \mathrm{kWh}
\end{aligned}
$$

0\&M:

$0 \&$ M Levelized Factor $=0$ \& M Present Worth Factor * Capital Recovery Factor

$$
=\left(\frac{1+e}{1-e}\right)\left[1-\left(\frac{1+e}{1+i}\right)^{n}\right] * \frac{i(1+i)^{n}}{(1+i)^{n}-1}
$$

where:

$$
\begin{aligned}
& e=\text { Annual } 0 \text { \& M Escalation Rate } \\
& i=\text { Heighted Cost of Money and Discount Rate } \\
& n=\text { Plant Life }
\end{aligned}
$$$$
0 \& M \text { Levelizing Factor }=\left(\frac{1.06}{.1-.06}\right)\left[1-\left(\frac{1.06}{1.10}\right)^{35}\right] * \frac{.1(1.1)^{35}}{(1.1)^{35}-1}
$$$$
=19.25 * .1037
$$$$
=1.996
$$

$\begin{aligned} \text { Levelized } 0 \& M \text { Cost }= & \text { Level ized Fixed } 0 \& M \text { Cost }+ \text { Levelized Variable } \\ & 0 \& M \text { Cost }\end{aligned}$

$$
\begin{aligned}
\text { Levelized Fixed } & =\frac{\$ 4.85 / \mathrm{kW} / \mathrm{yr}}{.25 * 8760} * 1.996 * 1000 \\
& =4.4 \mathrm{mi} 11 \mathrm{~s} / \mathrm{kWh}
\end{aligned}
$$

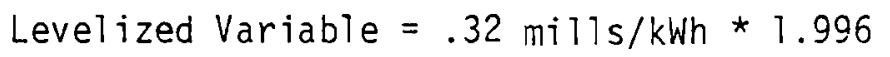

$$
=.6 \mathrm{mi} 11 \mathrm{~s} / \mathrm{kWh}
$$

Total Levelized $0 \& M$ Cost $=4.4+.6=5.0 \mathrm{mills} / \mathrm{k} 1 \mathrm{hh}$ 
Turbine Fuel:

Energy Levelizing Factor $=$ Energy Present Worth Factor * Capital Recovery Factor

$$
\begin{aligned}
& =\left(\frac{1.07}{.10-.07}\right)\left[1-\left(\frac{1.07}{1.10}\right)^{35}\right] * .1037 \\
& =22.12 * 1.037 \\
& =2.29
\end{aligned}
$$

Levelized Turbine Fuel Cost $=$ Base $\$ / G J * \frac{J}{W h}$ * Energy Levelizing Factor

$$
\begin{aligned}
& =\frac{\$ 4.74}{G J} * \frac{4648 \mathrm{~J}}{W h} * 2.29 * 10^{6} \\
& =50.5 \mathrm{mi} 11 \mathrm{~s} / \mathrm{kWh}
\end{aligned}
$$

Compression Energy:

Levelized Compression Energy Cost $=\frac{\text { Base mills } / \mathrm{kWh} * \text { Energy Levelizina Factor }}{\text { Coefficient of Performance }}$

$$
\begin{aligned}
& =\frac{30 * 2.29}{1.45} \\
& =47.4 \mathrm{mi} 17 \mathrm{~s} / \mathrm{k}: \mathrm{h} \\
\text { Total cost } & =26.8+4.4+.6+50.5+47.4 \\
& =129.7 \mathrm{mi} 11 \mathrm{~s} / \mathrm{k}^{1 \cdot} \cdot \mathrm{h}
\end{aligned}
$$




\section{TES-1 SYSTEM: LEVELIZED REVENUE REQUIREMENT}

Capital:

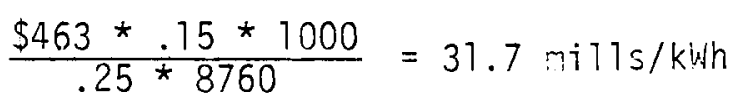

O \& M:

Same as Reference CAES system $=5.0 \mathrm{mills} / \mathrm{k} ! \mathrm{h}$

Turbine Fuel:

$$
\$ 4.74 / \mathrm{GJ} * 4289 \mathrm{~J} / \mathrm{Wh} * 2.29 * 10^{6}=4.6 .6 \mathrm{mi} 11 \mathrm{~s} / \mathrm{kWh}
$$

Compression Energy:

$$
\frac{30 * 2.29}{1.31}=52.4 \mathrm{mi} 11 \mathrm{~s} / \mathrm{kWh}
$$

Total Levelized Cost:

$$
31.7+5.0+46.6+52.4=135.7 \mathrm{mi1} 1 \mathrm{~s} / \mathrm{kwh}
$$


Capital:

$$
\frac{\$ 735 * .15 * 1000}{.25 \star 8760}=50.3 \mathrm{mi11} / \mathrm{s} / \mathrm{kWh}
$$

O \& M:

$$
\text { Same as Reference CAES system }=5.0 \mathrm{mil1 \textrm {s }} / \mathrm{kWh}
$$

Turbine Fuel:

$$
0
$$

Compression Energy:

$$
\frac{30 * 2.29}{.67}=102.5 \mathrm{mil1s} / \mathrm{kWh}
$$

Total Levelized Cost:

$$
50.3+5.0+102.5=157.8 \mathrm{mil1} / \mathrm{s} / \mathrm{kWh}
$$


TES-3 SYSTEM: LEVELIZED REVENUE REQUIREMENT

Capital:

$$
\frac{\$ 780 * .15 * 1000}{.25 * 8760}=53.4 \mathrm{mi} 11 \mathrm{~s} / \mathrm{kWh}
$$

$0 \& M$ :

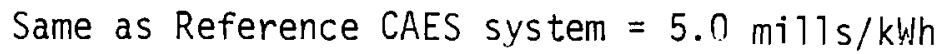

Turbine Fuel:

0

Compression Energy:

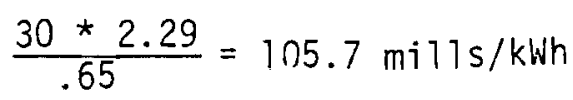

Total Levelized Cost:

$$
53.4+5.0+105.7=164.1 \mathrm{mi} 11 \mathrm{~s} / \mathrm{k} \mathrm{l} \cdot \mathrm{h}
$$




\section{TES-4 SYSTEM: LEVELIZED REVENUE REQUIREMENT}

\section{Capita 1:}

$$
\frac{\$ 478 * .15 * 1000}{.25 * 8760}=32.7 \mathrm{mi11} \mathrm{s} / \mathrm{kWh}
$$

O \& M:

$$
\text { Same as Reference CAES system }=5.0 \mathrm{mills} / \mathrm{kWh}
$$

Turbine Fuel:

$$
\$ 4.74 / \mathrm{GJ} * 3732 \mathrm{~J} / \mathrm{Wh} * 2.29 * 10^{6}=40.5 \mathrm{mills} / \mathrm{kWh}
$$

Compression Energy:

$$
\frac{30 * 2.29}{1.13}=60.8 \mathrm{mil1s} / \mathrm{kWh}
$$

Total Level ized Cost:

$32.7+5.0+40.5+60.8=139.0 \mathrm{mills} / \mathrm{kWh}$ 


\section{GT SYSTEM: LEVELIZED REVENUE REQUIREMENT}

Capital

$$
\frac{\$ 240 * .15 * 1000}{.25 * 8760}=16.4 \mathrm{mi} 11 \mathrm{~s} / \mathrm{kWh}
$$

O \& M:

Same as Reference CAES system $=5.0 \mathrm{mills} / \mathrm{kWh}$

Turbine Fue]:

$$
\$ 4.74 / \mathrm{GJ} * 12,133 \mathrm{~J} / \mathrm{Wh} * 2.29 * 10^{6}=131.7 \mathrm{mi11 \textrm {s }} / \mathrm{kWh}
$$

Total Level ized Cost:

$$
16.4+5.0+131.7=155.5 \mathrm{mi} 11 \mathrm{~s} / \mathrm{kWh}
$$


PNL -3118

UC-94b

\section{DISTRIBUTION}

No. of

Copies

OFFSITE

A. A. Churm

DOE Chicago Patent Group

Chicago Operations Office

9800 South Cass Avenue

Argonne, IL 60439

27 DOE Technical Information Center

B. J. Mueller

Department of Energy

Chicago Operations Office

9800 S. Cass Avenue

Argonne, IL 60439

Chief, APMBR

Division of Energy Storage Sys tems

U.S. Department of Energy

Washington, DC 20585

Dan Hall

P.0. 635

Fairvault, MN 55021

Royal B. Newman

Soyland Power Cooperative, Inc.

PO Box A7606

Decatur, IL 62525

G. D. Pezdirtz, Director

Division of Energy Storage Sys tems

U.S. Department of Energy

Washington, DC 20585
No. of

Copies

3 P. A. Thompson

DOE Division of Energy Storage Systems

Advanced Physical Methods

Branch

Washington, DC 20585

J. H. Swisher

Division of Energy Storage Systems

U.S. Department of Energy

Washington, DC 20585

D. W. Boehm

Division of Environmental Control Technology

U.S. Department of Energy

Washington, DC 20585

Assistant Director for Major Projects

Division of Solar Energy U.S. Department of Energy

Washington, DC 20585

Assistant Director for Thermal

Power Systems

Division of Solar Energy

U.S. Department of Energy

Washington, DC 20585

DOE Library

U.S. Department of Energy

Mail Station G-043

Washington, DC 20585

R.F. Kimberlin

DOE Library

U.S. Department of Energy

Room 1223

Washington, DC 20585 
No. of

Copies

D. Willett

Acres American, Inc.

Liberty Bank Building

Main at Court

Buffa1o, NY 14202

L. A. Wilson

Middle South Services

P.0. Box 61000

New Orleans, LA 70161

G. T. Flynn

Energy Systems Engineer

MIT/Lincoln Laboratory

Lexington, MA 02173

J. P. Joyce

NASA Lewis Research Center

21000 Brookpark Road

Cleveland, $\mathrm{OH} 44135$

Division of Advanced Energy

Research and Technology

National Science Foundation

Room 1140

1800 G Street, NW

Washington, DC 20550

C. G. Nelson

Manager, Storage Operations

Northern Illinois Gas

Company

P.0. Box 190

Aurora, IL 60507

P. E. Schaub

Potomac Electric Power Company

1900 Pennsylvania Avenue

Washington, DC 20006

T. McCafferty

Public Service Company

of Indiana

1000 E. Main Street

Plainfield, IN 46168
No. of

Copies

2 Technical Library

Department 3141

Sandia Laboratory

A1buquerque, NM 87115

J. Rasmussen

PEPCO

1900 Pennsylvania Avenue, N.W.

Washington, DC 20068

S. Serata

Serata Geomechanics, Inc.

1229 Eighth Street

Berkeley, CA 94710

Energy Research Section

Tennessee Valley Authority

1360 Commerce Union Bank B1dg.

Chattanooga, TN 37401

Gerald Phillips

Tennessee Valley Authority

Chattanooga, TN 37401

E. Berman

Technical Library

TRW Energy Systems Group

7600 Colshire Drive

McLean, VA 22101

E. H. King

Underground Design Consultants

820 Cascade Bldg.

Portland, OR 97204

A. I. Giramonti

United Technologies Research Center

Silver Lane

East Hartford, CT 06108

H. J. Pincus

University of Wisconsin

Department of Geological

Sciences

Sabin Hall and Greene Museum

P.O. Box 413

Milwaukee, WI 53201 
No. of

Copies

D. Ayers
Manager, Fluid Systems Laboratory
Westinghouse Electric Corporation

1291 Cumberland Avenue

West Lafayett, IL 47906

American Public Power Association

2600 Virginia Avenue, NW Washington, DC 20037

2 J. M. Clinch

Argonne National Laboratory

9700 South Cass Avenue

Argonne, IL 60439

Manager, Research and Development

Bonneville Power Administration

P.0. Box 3621

Portland, OR 97208

Research Library, Reference Section

Information Division

Brookhaven National Laboratory

Upton, NY 11973

Stanley Stys

Vice President, American

Brown Boveri Corporation

New Brunswick, NJ 08902

Director of Research

Cincinnati Gas and and Electric Company

139 East Fourth Street

Cincinnati, $\mathrm{OH} 45202$

D. E. DeViney

Commonwealth Edison Company

1319 South First Avenue

Maywood, IL 60153
No. of

Copies

\author{
R. A. Be11 \\ Consolidated Edison Company \\ 4 Irving Place \\ New York, NY 10003 \\ T. Schneider \\ Electric Power Research \\ Institute \\ Box 10412 \\ Palo Alto, CA 94303 \\ D. Anderson \\ Fenix and Scisson, Inc. \\ P.0. Box 15609 \\ Tulsa, OK 74115 \\ Director of Research \\ GPU Service Corporation \\ 260 Cherry Hill Road \\ Parsippany, NJ 07054
}

A. H. Barber

Director of Marketing

Harza Engineering Company

150 S. Wacker Drive

Chicago, IL 60606

Library

Lawrence Berkeley Laboratory

University of California

Bldg. 50, Room 134

Berkeley, CA 94720

3 Technical Information

Department, L-3

Lawrence Livermore Laboratory

University of California

P.0. Box 808

Livermore, CA 94550

Director of Research

Louisiana Power and Light

142 Delaronde Street

New Orleans, LA 70174 
No. of

Copies

I. Glendenning

Head of Long-Term Studies

Marchwood Engineering Labs

Southampton, England

A. Ferreira

- Electric Power Research

Institute

NEPLAN

174 Brush Hill Avenue

West Springfield, MA 01089

W. Stevens

Project Manager

Electric Power Research

Institute

3412 Hillview Avenue

PO Box 10412

Palo Alto, CA 94303

Fred Ahrens

Argonne National Laboratory

9700 South Cass Avenue

Argonne, IL 60439

Paul Gnirk

$\mathrm{Re} / \mathrm{Spec}$ Inc.

PO Box 725

Rapid City, SD 57701

Donald L. Katz

Department of Chemical

Engineering

The University of Michigan

2042 E. Engr. Bldg.

Ann Arbor, MI 48109

Bob Holliday

Project Manager

Department of Energy

600 "E" Street

Washington, D.C. 20545

R. L. Thoms

Louisiana State University

Institute for Environmental

Studies

Room 42, Atkinson $\mathrm{Hall}$

Baton Rouge, LA 70803
No. of

Copies

0.C. Farquhar

U. of Massachusetts

Dept. of Geology \& Geography

Morrill Science Center

Amherst, MA 01003

T. L. Brekke

University of California

Department of Civil Engineering

1847 Yosemite Road

Berkeley, CA 94707

H. Lorenzen

PB-KBB Inc.

Subservice Systems \& Technology

800 Commerce Road West

Harahan, LA 70123

A. H. Warnke

Vice President Power Supply

Central Illinois Public Service Co.

607 East Adams Street

Springfield, IL 62701

Mr. G. E. Huck

Manager of Planning

111 ino is Power Company

500 South 27 th St.

Decatur, IL 62525

Mr. W. C. Walke

Project Manager

Sargent \& Lundy Engineers

55 East Monroe Street

Chicago, IL 60603

T. J. Maiman

Sta. Mech. Engr. Dept. Manager

Commonwealth Edison Co.

36 FN West

PO Box 767

Chicago, IL 60690

E. M. Mabuce

Manager-Applied Research

Corporate Planning Dept.

Union Electric. Co.

PO Box 149

St. Louis, MO 63166 
No of

Copies

W. F. Kobett

CAES Project Manager

Westinghouse Electric Corp.

Combustion Turbine Sys. Div.

Long Range Development-Lab 100

PO Box 251

Concordville, PA 19331

6 C. A. Knutsen

Knutsen Research Services

14705106 th Avenue, N.E.

Bothe11, WA 98011

ONSITE

DOE Richland Operations

Office

D. K. Jones

H. E. Ransom

Pacific Northwest Laboratory

R.D. Allen

R.T. Al lemann

J.M. Bates

H.J. Bomelburg

D.B. Cearlock

T.J. Doherty

D.W. Dragnich

M.K. Drost

R.L. Erikson

J.A. Fort

J.R. Friley

P.J. Gutknecht

A.J. Haverfield

J.J. Jacobson

L.D. Kannberg

W.V. Loscutoff (30)

R.A. McCann

M.A. McKinnon

D.A. Myers

L.T. Pedersen

R. Reilly
No. of

Copies

Pacific Northwest Laboratory

R.P. Smith

J.A. Stottlemyre

A.M. Sutey

D.S. Trent

R.A. Walter

L.E. Wiles

Technical Information (5)

Publishing Coordination (2) 
: 